\title{
Forensic igneous petrology: locating the source quarry for the "black granite" Titanic headstones in Halifax, Nova Scotia, Canada
}

\author{
D. Barrie Clarke ${ }^{*}$, Christopher R. M. McFarlane ${ }^{2}$, David Hamilton ${ }^{3}$, and \\ DAVID STEVENS 4 \\ 1. Department of Earth Sciences, Dalhousie University, Halifax, Nova Scotia B3H 4R2, Canada \\ 2. Department of Earth Sciences, University of New Brunswick, Fredericton, New Brunswick E3B 5A3, Canada \\ 3. Department of Mathematics and Statistics, Dalhousie University, Halifax, Nova Scotia B3H 4R2, Canada \\ 4. 5175 Route 127, Bocabec, New Brunswick E5B 3H3, Canada \\ *Corresponding author <clarke@dal.ca $>$
}

Date received: 29 February 2016 Date accepted: 21 September 2016

\begin{abstract}
In Halifax, Nova Scotia, 149 victims of the 1912 sinking of the Titanic lie beneath petrologically identical "black granite" headstones. Those headstones, supplied by the White Star Line, arrived in Halifax in late 1912, but no known historical document reveals their source. They consist of medium- to coarse-grained olivine-bearing gabbro, with cumulus phases consisting of randomly oriented euhedral plagioclase laths, corroded olivine, and titaniferous magnetite, and intercumulus material consisting of augite with reaction rims of hornblende, both of which are variably altered to actinolite and biotite. Three types of forensic evidence [quantitative - radiometric age of $422.1 \pm 1.3 \mathrm{Ma}(\mathrm{n}=17)$, mean olivine $\mathrm{FeO} /(\mathrm{FeO}+\mathrm{MgO})$ values ranging from 0.43 to 0.46 , augite rim traceelement compositions (35 elements), and whole-rock chemical compositions ( 48 elements), including statistical analysis of all these data showing no significant differences between the headstones and their putative source quarry; qualitative - mineral assemblages, modal proportions, textural parameters, style and degree of alteration; and circumstantial - regional reputation, quarrying history, local logistics, regional transportation, McGrattan marker] connect the Titanic headstones to the Saint George Batholith in southwestern New Brunswick. Precise matching of any dimension stone to its source quarry is problematic, because that material connects only to a void in the quarry. Ideally, all physical-chemical-temporal properties of the dimension stone and source quarry should match, both quantitatively and qualitatively, but in reality only the ages must almost certainly match. Thus it is remotely possible for the right quarry to mismatch most of the properties of the dimension stone, and for a wrong quarry to match most of the properties of the dimension stone. However, in the case of the Titanic headstones, the cumulative weight of all the quantitative, qualitative, and circumstantial evidence, combined with a process of elimination and application of Ockham's razor, indicate that the Charles Hanson quarry near Bocabec, southwestern New Brunswick, is the likely source for the gabbroic Titanic headstones in Halifax, Nova Scotia.
\end{abstract}




\title{
RÉSUMÉ
}

\begin{abstract}
À Halifax, en Nouvelle-Écosse, 149 victimes du naufrage du Titanic, qui a eu lieu en 1912, reposent sous des pierres tombales dont la composition pétrologique est identique à celle du "granit noir». Ces pierres tombales fournies par la White Star Line sont arrivées à Halifaxà la fin del'année 1912, mais aucun document historique connun'indique leur provenance. Il s'agit de gabbro comportant des grains d'olivine moyens à grossiers, dont les cumulus sont composés de lattes de plagioclase idiomorphe orientées de manière aléatoire, d’olivine corrodée et de magnétite titanifère, avec un intercumulus composé d'augite et de couronnes réactionnelles en hornblende, qui s'altèrent tous les deux de manière variable en actinote et en biotite. Trois types de preuves scientifiques [quantitative - âge radiométrique de $422,1 \pm 1,3 \mathrm{Ma}(\mathrm{n}=17)$, valeurs moyennes d’olivine $\mathrm{FeO} /(\mathrm{FeO}+\mathrm{MgO})$ comprises entre 0,43 et 0,46 , éléments-traces présents dans la composition de la couronne en augite (35 éléments),et compositions chimiques des roches (48 éléments), y compris l’analyse statistique de toutes ces données qui ne montre aucune différence majeure entre les pierres tombales et leur carrière de provenance présumée; qualitative - assemblages minéraux, proportions modales, paramètres de texture, style et degré d’altération; et circonstancielle - notoriété régionale, histoire de l'exploitation des carrières, logistique locale, transport régional, marque de McGrattan] lient les pierres tombales des victimes du Titanic au batholite de Saint George dans le sud-ouest du Nouveau-Brunswick. Faire correspondre précisément une pierre de taille avec la carrière d’où elle provient est problématique, car le matériau est seulement lié à l'absence d'une pierre dans la carrière. En principe, toutes les propriétés physiques, chimiques et temporelles de la pierre de taille devraient correspondre à celles de la carrière de provenance, aussi bien de manière quantitative que qualitative, mais en réalité, seulement leurs âges respectifs doivent presque assurément correspondre. Ainsi, il n’est pas absolument impossible que les propriétés de la carrière qui est la bonne ne correspondent pas à la plupart des propriétés de la pierre de taille, et que celles d'une autre carrière, qui n'est pas la bonne, correspondent à la plupart des propriétés de la pierre de taille. Toutefois, dans le cas des pierres tombales des victimes du Titanic, l'accumulation des éléments de preuves quantitatives, qualitatives, et circonstancielles, associés à un processus d'élimination et d'application du rasoir d'Ockham, indique que les pierres tombales en gabbro, situées à Halifax, en Nouvelle-Écosse, proviennent probablement de la carrière Charles Hanson, située à proximité de Bocabec, dans le sud-ouest du Nouveau-Brunswick.
\end{abstract}

[Traduit par la redaction]

\section{INTRODUCTION}

Most people know about the sinking of the Titanic on its maiden voyage in 1912; relatively few people know that 149 of the 150 victims buried in three cemeteries in Halifax, Nova Scotia, lie under petrologically identical gabbroic headstones (Fig. 1a); and, until this investigation, no one knew where those headstones originated. In fact, no one particularly wanted to know until, in 1997, in the wake of the "Titanic" film by James Cameron and the subsequent influx of visitors to those cemeteries, the City of Halifax sought to replace the frost-damaged headstone of Thomas F. Baxter (Fig. 1b). The absence of any historical record of the source quarry, in newspapers, archival documents, or shipping records, meant that this question about the source had to be solved scientifically. Unlike most academic petrogenetic problems with several hypothetical answers, this practical problem has only one unequivocal answer. This paper provides our scientific answer to the question of the origin of the Titanic headstones.

\section{Definitions}

Two terms from the title require some elaboration. "Forensic" refers to evidence suitable for presentation in a court of law and, in this case, the jury consists of scientific peers who ultimately determine whether the evidence we have collected is suitable to support our conclusion that we have located the source quarry for the Titanic headstones. "Black granite" is the dimension-stone-industry term for gabbro.

\section{Principles guiding the search}

Over the course of this investigation, 10 principles emerged for narrowing this search, and they should be useful for any similar type of search in future. These principles are as follows:

\section{Principle 1 - sampling limitations}

Ideally, the source quarry should match the physicalchemical-chronological characteristics of the Titanic headstones, with the following caveats: (1) measurements on the Titanic headstones are extremely limited - only one (Thomas F. Baxter) of the 149 Titanic headstones could be sampled, and even then there were only three small pieces, with the subsequent addition of a much larger sample from the Titanic-lookalike headstone belonging to A. Susan Ritcey (1916) (Figs. 2a, b). Although the Titanic headstones appear to be uniform macroscopically, the extent of physicalchemical variation in all 149 Titanic headstones presumably exceeds the (small) variation in the Baxter-Ritcey pair, but the extent of this variation is unknown and is not easy to determine. We could photograph every headstone and do image analysis, or we could use a portable XRF to measure the chemical variation in all Titanic headstones (but for such coarse-grained rocks, the analytical precision is not as good as ICP-MS analyses of whole-rock powders). (2) Similar constraints apply to the putative source quarry the headstones are not necessarily now represented by the current walls and floor of the quarry, but rather by some 

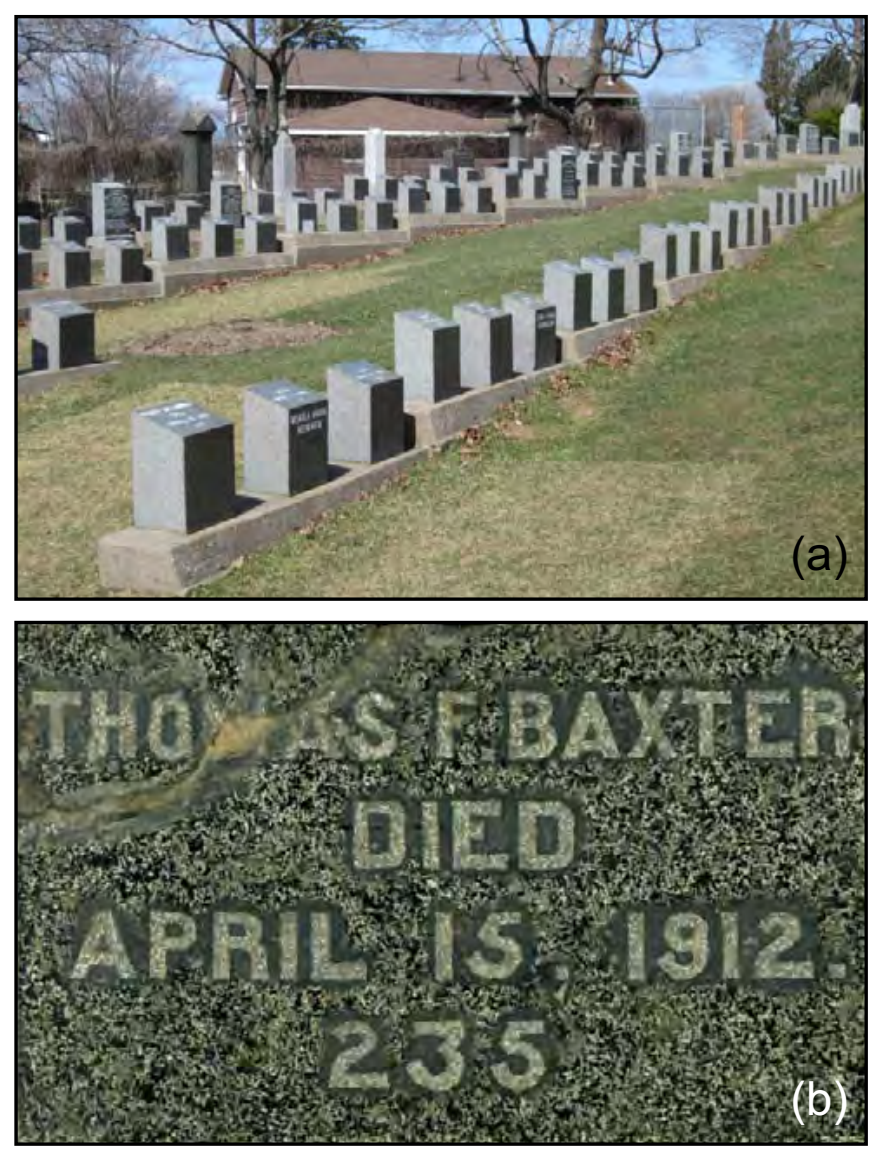

Figure 1. Titanic Headstones. (a) Fairview Lawn Cemetery, Halifax, showing many of the Titanic headstones, most of which have the same chisel shape, with polish on only the top and front surfaces. (b) The original top surface of the Baxter headstone, showing its "snowflake" texture and damaged upper left corner. The need to replace this damaged stone led to this investigation.

unknown part of the empty excavation. Depending on the nature of the variation in the walls and floor of the quarry, we may or may not be able to interpolate from those locations to the headstones. We take up this matter again in the Discussion.

The consequence of this principle is that any failure to precisely match headstones and quarry may be partly a function of limited opportunity to establish the extent of variation in Titanic headstones, and partly a function of not being able to know what the precise physical-chemical properties of the rocks were in the cavity now remaining at the quarry location.

\section{Principle 2 - geochronology}

Two petrologically similar samples taken from a single quarry in a single pluton are highly unlikely to have significantly different ages. All physical variants of this pluton (e.g., fine-grained marginal chill, medium-grained main body, coarse-grained late-stage pegmatites) and all chemical variants (resulting from differentiation and alteration) should at least have the same initial radiometric age. Conversely, no matter how many other parameters match, if the ages of headstone and candidate source quarry do not match, we probably have not located the source. Thus, accurate and precise radiometric age determination is paramount, and a matching age is a necessary, but normally insufficient condition on its own, for establishing a link.

\section{Principle 3 - comparing textures}

Textures, involving grain sizes, grain shapes, grain orientations, and grain inter-relations, are difficult to quantify, but the human brain is an excellent patternrecognition machine, and we can commonly determine at a glance whether one texture is a good match for another, particularly in the matter of grain size, modal proportions of felsic and ferromagnesian minerals, and grain orientations. Early in this investigation, we used a large 1:1 scale, plasticlaminated photograph of a Titanic headstone during the cemetery-search stage of the investigation (Principle 5 below), but latterly we replaced this photograph with an even more authentic polished slab of the Susan Ritcey headstone. "Black granites" are highly variable in their textures, and detecting a macroscopic textural match is not particularly difficult. On a microscopic scale, it is possible to identify qualitatively many textural features between different types of grains. To find a quarry in which many textural parameters are qualitatively the same as the headstones would be improbable, unless they are from the same pluton.

\section{Principle 4 - comparing chemical compositions of rocks and minerals}

When comparing whole-rock chemical compositions of headstone and quarry, there should be few problems. When comparing the compositions of chemically zoned minerals, such as olivine and augite, the problem is that the cores and rims, even of individual grains, may be so different that we could demonstrate statistically that they do not belong to the same population. Clearly this is not the case. Because it is not necessarily true that the center of a 2-D section through a mineral grain is also the $3-\mathrm{D}$ center of that grain, we cannot compare mineral cores. On the other hand, the $2-\mathrm{D}$ rims are the same as the 3-D rims, so only comparisons involving rims of zoned minerals are valid.

\section{Principle 5 - cemeteries as proxies for quarries}

In the early $20^{\text {th }}$ Century, as a consequence of poor roads and paucity of motor vehicles, most materials and foodstuffs 

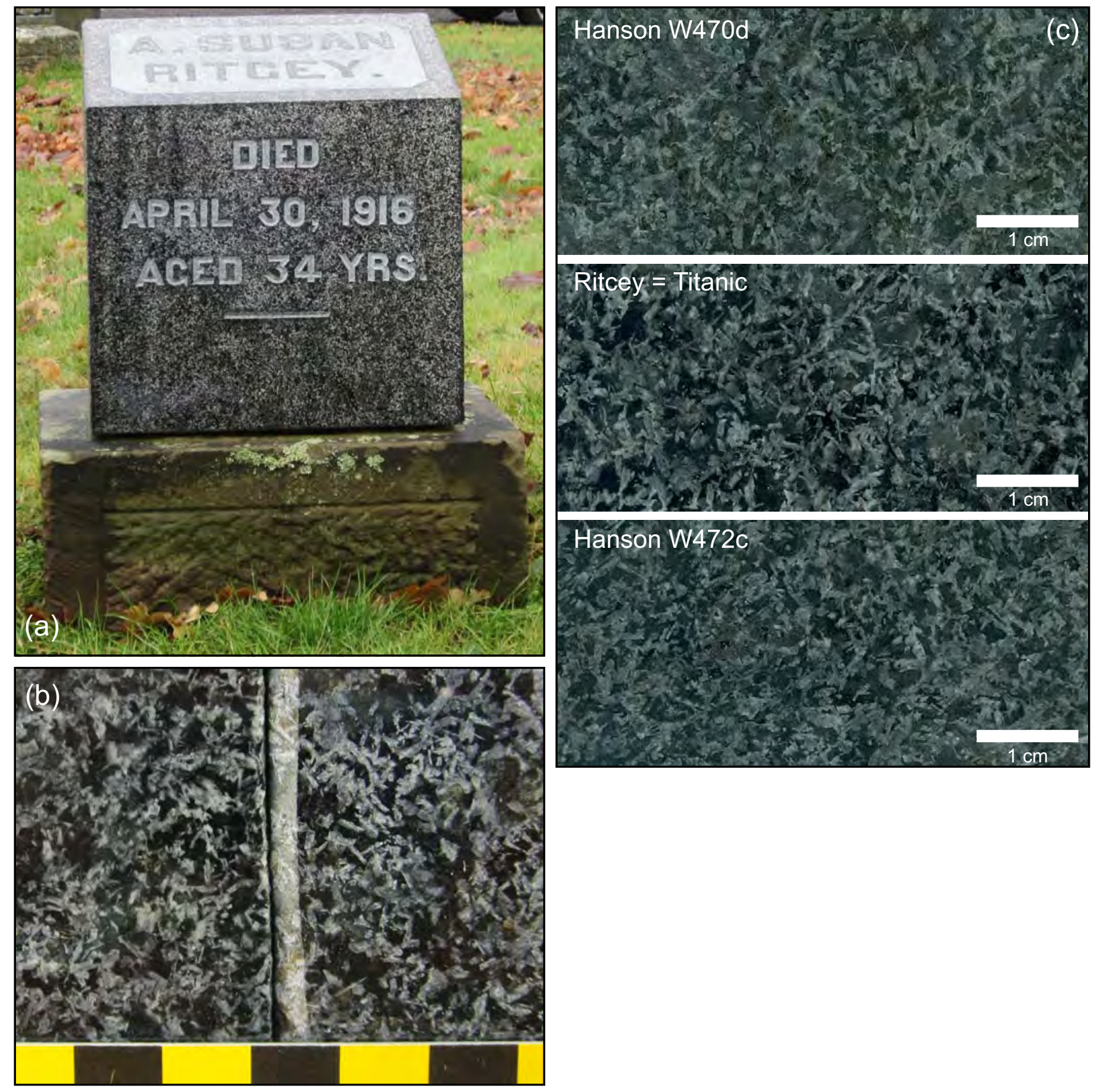

Figure 2. Macroscopic comparisons of the Ritcey headstone, Titanic headstone, and Hanson quarry. (a) Headstone of A. Susan Ritcey (1916) is the same size, and has the same chisel shape, as many of the Titanic headstones. The importance of the Ritcey headstone was to provide a second sample of Titanic material. (b) Ritcey headstone (right) has the same "snowflake" texture as the Baxter headstone (left). Scale division are in cm. (c) Textural comparison of the Ritcey headstone and two samples from the Hanson quarry. 
were sourced and/or produced locally. This limitation means that, unlike in the early $21^{\text {st }}$ Century, when many products are global in origin, most dimension stone from a century ago did not normally travel great distances; therefore, local material dominates in century-old parts of each cemetery, and thus cemeteries of that age serve as proxies for local geology and local quarries. And because old cemeteries are much easier to find than old quarries, it is logical to search in cemeteries first, and then deduce that the source quarries may be nearby. The headstones also have the advantage of being clearly dated (one needs only to examine that part of the cemetery developed in the early $20^{\text {th }}$ Century) and they avoid the inherent difficulty of comparing polished headstone material with roughly fractured and weathered quarry material. So, it is possible to postpone the difficult search for overgrown quarries until headstones with good textural matches become common in cemeteries.

\section{Principle 6 - locating old quarries}

Finding even decade-old quarries is difficult because they quickly become overgrown; finding century-old quarries is nearly impossible. Publications by Parks (1914), Wright (1934), and Martin $(1990,2013)$ contain useful information about the existence, general location, and operational histories of some of the better-known quarries in southwestern New Brunswick. To find the precise locations, modern aerial photography and satellite imagery are not useful. Instead, the solution to this problem is to examine the oldest available aerial photographs, locate the quarrying operations, transfer their locations to Google Earth $^{\mathrm{Tm}}$, determine their latitudes and longitudes, enter those coordinates into a hand-held GPS, and then walk directly through the woods to the former excavations. In this investigation, we used the 1935 air photos to find the "black granite" quarries in the St. George - St. Andrews - St. Stephen area of southwestern New Brunswick, and successfully located 16 of them, although two were not truly gabbroic. Confirmation of a quarry location comes in the form of obvious excavations, prominent drill marks, heaps of quarried but not transported blocks, and the presence of some pieces of derelict quarrying equipment (bits, anchors, tools).

\section{Principle 7 - quarry operational history}

Historical records of quarrying operations, if they are available and reliable, can be useful (Parks 1914; Martin 2013). In the case of the 1912 Titanic headstones, it would be impossible to obtain that dimension stone from a quarry that opened in 1917, but a quarry that opened in 1890 , and possibly even closed in 1900, could be a candidate because stockpiling could have taken place. Better still would be a quarry that was fully operational in 1912 and could fill a large order on short notice.

\section{Principle 8 - local transportation logistics}

In the case of several possible local source quarries with the right operational history and similar temporalphysical-chemical characteristics, the one with the easiest transportation link to the site of cutting and polishing is the most likely.

\section{Principle 9 - qualitative sameness}

Establishing the sameness of two or more samples of Earth materials is central to the science of forensic geology. In his classic book on forensic geology, Murray (2004) states: "If we were to take a rock from any outcrop and break it in two, in most cases it would be possible to show, through detailed study, differences between the two pieces. In most cases, however, the similarity between the two pieces would be large. We would be able to say that they compare and that there is a high probability that one piece was a sample of the other, meaning they had a common source." For any qualitative parameter (mineral assemblage, texture), we can state only that observations taken from the two populations (headstones and quarry) are identical or similar or different. For example, if the headstone and candidate quarry have the same mineral assemblage and one shared textural feature, they may be the same, but if they have the same mineral assemblage and many shared textural features (Fig. 2c), they are more likely to be the same.

\section{Principle 10 - quantitative sameness}

For any quantitative parameter (e.g., age, chemical composition), we can use appropriate objective statistical tests to look for differences between the means of the headstone and quarry populations. Alternatively, if we compare multivariate data with $x$ criteria, and obtain a perfect match for $x-1$ of them but the remaining criterion does not match, then there might not be a match. However, this condition applies to a perfect non-geological world where we know all the variation in the Titanic headstones (we cannot, and do not) and we know all the variation in the candidate quarry (we cannot, and do not).

\section{Purpose/agenda}

Using the principles above, we now present the quantitative, qualitative, and circumstantial evidence that the Charles Hanson quarry in Bocabec, New Brunswick (Fig. 3) is the source of the Titanic headstones in Halifax, Nova Scotia, approximately $500 \mathrm{~km}$ distant. We present this supporting evidence in order from the strongest quantitative to moderate qualitative to weakest consequential. In a departure from the format of a conventional scientific paper, we evaluate the strength of the evidence immediately following its presentation. 


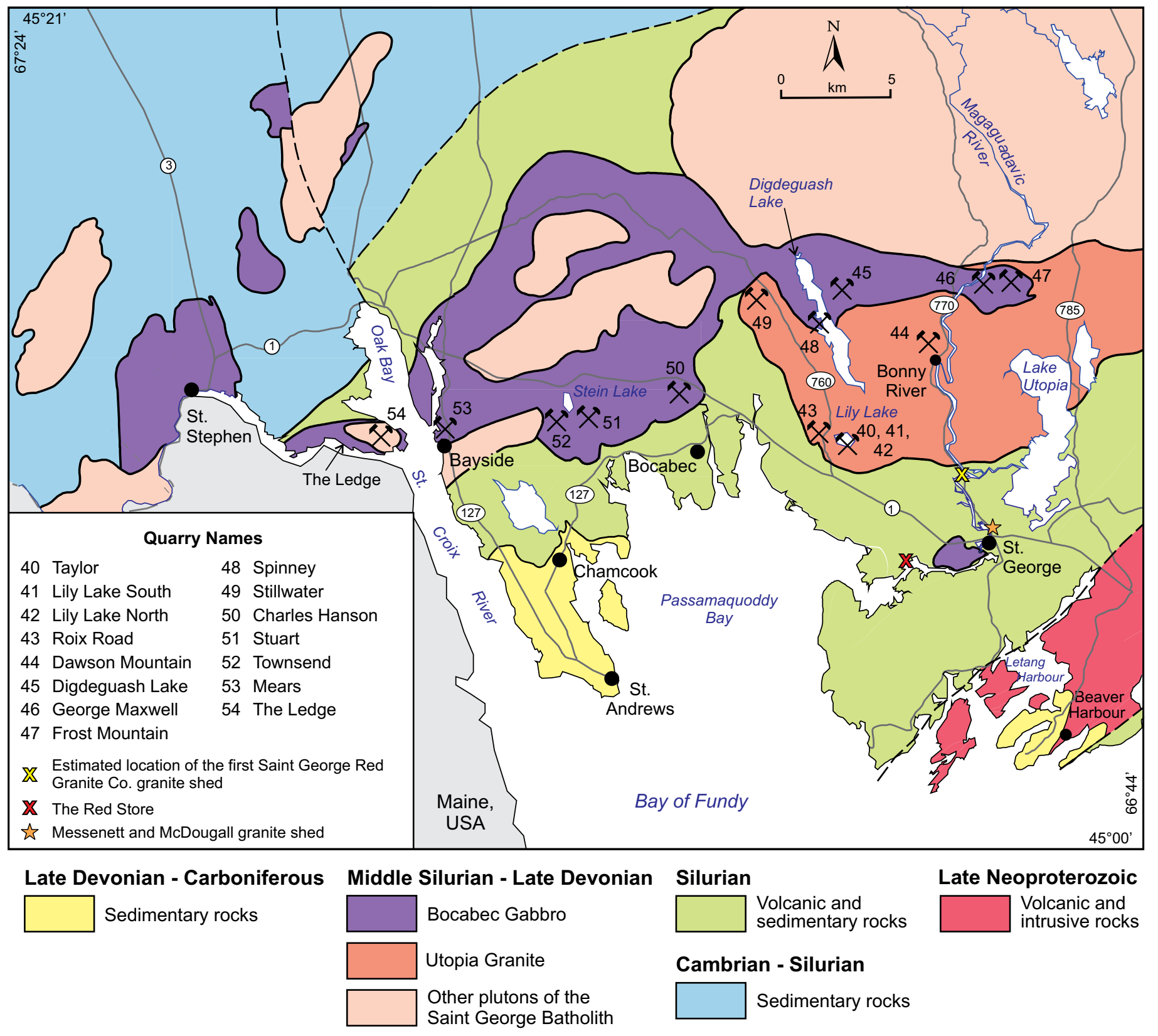

Figure 3. Geological map of southwestern New Brunswick (Martin 2013, with permission), showing the Bocabec gabbro, the locations of important quarries (crossed hammers symbol), and some sense of the ease of transportation of material from these quarries to St. George, "The Granite Town”, in the southeastern quadrant of the map.

\section{SCIENTIFIC QUANTITATIVE EVIDENCE}

\section{Geochronology}

According to Principle 2, a matching age for headstone and quarry is a necessary, but on its own insufficient, condition to establishing a connection between them. A matching age for the Titanic headstones and candidate quarry is, therefore, the one quantitative value that must fit independent of any variation in mineralogy, texture, or bulk chemical composition.

Figure 4 and Table 1 show the results of the zircon age determinations by LA-ICP-MS. A combination of minor inheritance of older material, apparent recent $\mathrm{Pb}$ loss (pulling points to younger ages), and incorporation of common $\mathrm{Pb}$ has affected the grains. In most cases there was enough common $\mathrm{Pb}$ to apply a ${ }^{204} \mathrm{~Pb}$-based correction to the data. In other cases we used a ${ }^{208} \mathrm{~Pb}$-based correction if 

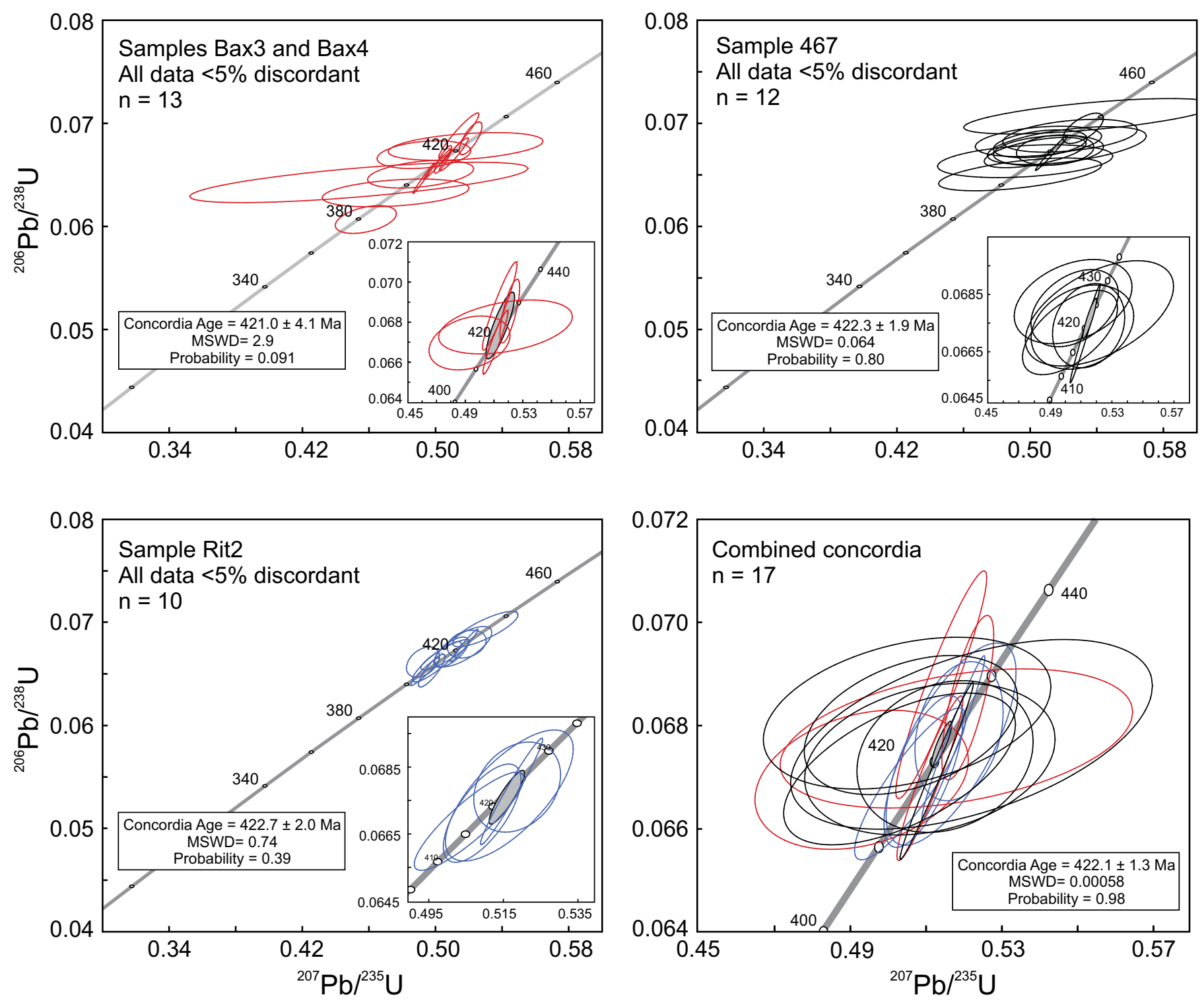

Figure 4. LA ICP-MS concordia plots for Titanic headstones (Bax3, Bax4, and Rit2) and Hanson quarry (467). Details in text and Appendix.

the measured ${ }^{204} \mathrm{~Pb}$ was too low. A few data points required no common $\mathrm{Pb}$ correction (e.g., Rit2-z1 - 5 in Table 1). Spots that record recent $\mathrm{Pb}$ loss and those with inheritance (presumably xenocrystic cores) were additionally filtered out until a single cluster of three or more near-concordant data produced a weighted-mean concordia age. These clusters typically comprise a combination of ${ }^{204} \mathrm{~Pb}$-corrected, ${ }^{208} \mathrm{~Pb}$ corrected, and uncorrected data. Using this approach, the Baxter headstone has a concordant age of $421.0 \pm 4.1 \mathrm{Ma}$, and a weighted-mean ${ }^{206} \mathrm{~Pb} /{ }^{238} \mathrm{U}$ age of $422.1 \pm 3.5 \mathrm{Ma}(\mathrm{n}$ $=5$ ). The Ritcey headstone has a concordant age of 422.7 $\pm 2.0 \mathrm{Ma}$, and a weighted-mean ${ }^{206} \mathrm{~Pb} /{ }^{238} \mathrm{U}$ age of $420.8 \pm$ 3.4 Ma $(\mathrm{n}=5)$. The Hanson quarry sample W467 has a concordant age of $422.3 \pm 1.9 \mathrm{Ma}$, and a weighted-mean ${ }^{206} \mathrm{~Pb} /{ }^{238} \mathrm{U}$ age of $421.9 \pm 3.0 \mathrm{Ma}(\mathrm{n}=7)$. All errors are $2 \sigma$. In combination, these three samples (Baxter, Ritcey, Hanson) yield a concordant age of $422.1 \pm 1.3(\mathrm{n}=17)$. The low MSWD (0.00058) for this data set indicates that there is no excess scatter beyond random analytical errors.

According to Murray (2004), "Finding similar properties in two samples does not in itself prove a common source. The significance of such evidence is determined by probability and statistics." In the case of the LA-ICP-MS zircon ages, the chi-squared test for homogeneity (Kalbfleisch 1985) gives a significance probability $\mathrm{P}=0.83$, showing no evidence against the null hypothesis that the mean zircon ages of Baxter, Ritcey, and Hanson quarry are not different. 
Table 1. Results for in situ LA ICP-MS U-Pb zircon dating. Samples marked with an asterisk in the third column are those used for the concordia plot and statistical analysis. Abbreviations: Bax - Baxter headstone, HQB - Hanson Quarry Bocabec, Rit - Ritcey headstone, and THH - Titanic Headstones Halifax.

\begin{tabular}{|c|c|c|c|c|c|c|c|c|c|c|c|c|c|c|c|c|}
\hline & & & & & & & & & $\mathrm{F}$ & $\mathrm{F}$ & & & & Age & & \\
\hline Spot & & conc & & & ${ }^{204} \mathrm{~Pb}$ & 1 & ${ }^{206} \mathrm{~Pb} /$ & & ${ }^{207} \mathrm{~Pb} /$ & $2 \sigma$ & ${ }^{206} \mathrm{~Pb} /$ & & & ${ }^{206} \mathrm{~Pb} /$ & & $\%$ \\
\hline THH Bax3-z1 - 1 & $a$ & 597 & 808 & 0.74 & 47 & 17 & 2063 & 99.19 & 0.501 & 0.007 & 0.0661 & 0.0012 & 0.986 & 412 & 7 & 100.0 \\
\hline THH Bax3-z1 - 2 & $a^{*}$ & 682 & 28 & 24.4 & 41 & 13 & 2039 & 99.28 & 0.521 & 0.006 & 0.0686 & 0.0013 & 0.749 & 427 & 8 & 100.4 \\
\hline THH Bax3-z1 - 4 & $a *$ & 716 & 30 & 23.8 & 75 & 23 & 1015 & 97.94 & 0.511 & 0.007 & 0.0670 & 0.0013 & 0.945 & 418 & 8 & 99.6 \\
\hline THH Bax3-z1 - 5 & $\mathrm{a}$ & 1078 & $4 \mathrm{~J}$ & 25.4 & 152 & 42 & 657 & 97.36 & 0.493 & 0.005 & 0.0647 & 0012 & 0.988 & 404 & 7 & 99.4 \\
\hline THH Bax3-z2 - 1 & $\mathrm{x}$ & 4500 & 204 & 22 & 1580 & 170 & 143 & 87.46 & 0.44 & 0.025 & 0.0607 & 0.0013 & 0.186 & 380 & 8 & 105.4 \\
\hline ТHН Bax3-z4 - 1 & $\mathrm{x}$ & 8420 & 292 & 28.8 & 239 & 33 & 1392 & 98.61 & 0.458 & 0.015 & 0.0607 & 0.0011 & 0.423 & 380 & 7 & 99.3 \\
\hline THH Bax3-z5 - 1 & $\mathrm{x}$ & 280 & 28 & 10 & 443 & 44 & 207 & 91.04 & 0.454 & 0.083 & 0.0643 & 0.0016 & 0.696 & 402 & 10 & 99.6 \\
\hline THH Bax3-z5 - 2 & $x^{*}$ & 499 & 年 & 17.2 & 318 & 22 & 337 & 93.94 & 0.518 & 0.038 & 0.0678 & 0.0011 & 0.379 & 423 & 7 & 100.9 \\
\hline THH Bax3-z6 - 1 & $\mathrm{x}$ & 3256 & 122 & 26.8 & 155 & 17 & 1421 & 98.63 & 0.476 & 0.036 & 0.0633 & 0.0011 & 0.341 & 395 & 7 & 100.3 \\
\hline THH Bax4-z1 - 1 & $\mathrm{x}$ & 697 & 01 & 11.5 & 1079 & 55 & 86 & 78.79 & 0.429 & 0.11 & 0.0645 & 0.0019 & 0.207 & 403 & 11 & 119.2 \\
\hline THH Bax4-z2 - 1 & $x^{*}$ & 2159 & 91 & 23.7 & 454 & 30 & 472 & 96.21 & 0.493 & 0.023 & 0.0670 & 0.0011 & 0.285 & 418 & 7 & 103.2 \\
\hline THH Bax4-z2 - 2 & $\mathrm{x}$ & 7740 & 312 & 24.8 & 869 & 78 & 406 & 95.54 & 0.491 & 0.026 & 0.0651 & 0.0011 & 0.387 & 406 & 7 & 100.1 \\
\hline THH Bax4-z3 - 1 & $\mathrm{a}$ & 399 & 162 & 7 & 239 & 64 & 10 & 1 & 5 & 0 & 55 & 11 & 0.871 & 415 & 6 & 100.1 \\
\hline THH Bax4-z3 - 2 & $a^{*}$ & 25 & 110 & 23.5 & 59 & 4 & 3000 & 99.55 & 0.514 & 01 & 0.0688 & 8 & 0.939 & 429 & 11 & 102.0 \\
\hline THH Rit2-z1 - 1 & $\mathrm{a}$ & $24 \angle 0$ & (1) & 24.4 & 39 & 10 & 5733 & 99.66 & 0.501 & 0.012 & 0.0662 & 0.0016 & 0.004 & 413 & 10 & 100.2 \\
\hline THH Rit2-z1 - 2 & $\mathrm{a}$ & 2432 & 89 & 27.2 & 32 & 21 & 8063 & 99.64 & 0.494 & 0.007 & 0.0652 & 0.0011 & 0.950 & 407 & 7 & 100.0 \\
\hline THH Rit2-z1 - 3 & $\mathrm{x}$ & 1234 & 65 & 19.1 & 455 & 36 & 285 & 93.39 & 0.527 & 0.046 & 0.0668 & 0.0013 & 0.453 & 417 & 8 & 96.2 \\
\hline THH Rit2-z1 - 4 & $a *$ & 2533 & 103 & 24.5 & 25 & 15 & 9108 & 99.85 & 0.509 & 0.009 & 0.0671 & 0.0012 & 0.685 & 419 & 7 & 100.2 \\
\hline THH Rit2-z1 - 5 & * & 2729 & 108 & 25.2 & -7 & 15 & -37271 & 99.97 & 0.519 & 0.01 & 0.0679 & 0.0011 & 0.273 & 424 & 7 & 99.8 \\
\hline THH Rit2-z1 - 6 & $a *$ & 4309 & 157 & 27 & 42 & 25 & 8757 & 99 & 0.506 & 0.012 & 0.0669 & 12 & 0.874 & 417 & 7 & 100.4 \\
\hline $\mathrm{TH}$ & $\mathrm{a}$ & T & 21 & 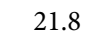 & 76 & 20 & 3 & 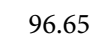 & .498 & 0.007 & 0.0653 & 0.0013 & 0.847 & 408 & 8 & 99.5 \\
\hline THH Rit2-z2 - 2 & $\mathrm{a}$ & 324 & 14 & 22.4 & 36 & 15 & 1146 & 98.79 & 0.53 & 0.016 & 0.0694 & 0.0014 & 0.812 & 432 & 9 & 100.1 \\
\hline THH Rit2-z2 - 3 & & 193 & 8 & 25.4 & 14 & 19 & 2749 & 99.39 & 0.562 & 0.016 & 0.0679 & 0.0012 & 0.274 & 423 & 8 & 93.3 \\
\hline THH Rit2-z2 - 4 & $a *$ & 172 & 8 & 20.7 & 118 & 52 & 256 & 97.8 & 0.517 & 0.014 & 0.0677 & 0.0016 & 0.706 & 422 & 10 & 99.8 \\
\hline THH Rit2-z2 - 5 & $a *$ & 415 & 17 & 24.1 & 30 & 15 & 1970 & 98.98 & 0.517 & 0.007 & 0.0678 & 0.0013 & 0.977 & 423 & 8 & 99.9 \\
\hline THH Rit2-z2 - 7 & a & 686 & 26 & 26.3 & 28 & 17 & 323 & 999 & 0.492 & 0.008 & 0.0662 & 0.0012 & 0.387 & 413 & 8 & 101.5 \\
\hline HQB 464-z1 - 1 & $\mathrm{x}$ & 4090 & 161 & 25.4 & 1085 & 85 & 262 & 93.21 & 0.497 & 0.043 & 0.0663 & 13 & 0.309 & 414 & 8 & 100.0 \\
\hline HQB 467-z1 - 2 & $a *$ & 412 & 17 & 24.2 & 111 & 31 & 805 & 97.62 & 0.513 & 0.008 & 0.0671 & 0.0014 & 0.987 & 419 & 9 & 99.5 \\
\hline HQB 467-z3 - 1 & $\mathrm{x}$ & 395 & 22 & 18.1 & 242 & 22 & 340 & 94.69 & 0.494 & 0.04 & 0.0651 & 0.0013 & 0.567 & 406 & 8 & 99.6 \\
\hline HQB 467-z3 - 10 & $x^{*}$ & 4385 & 193 & 22.7 & 277 & 30 & 1484 & 98.73 & 0.511 & 0.027 & 0.0674 & 0.0012 & 0.261 & 420 & 8 & 100.4 \\
\hline HQB 467-z3 - 11 & $x^{*}$ & 1178 & 70 & 16.9 & 565 & 35 & 430 & 95.71 & 0.503 & 0.025 & 0.0672 & 0.0012 & 0.584 & 419 & 8 & 101.7 \\
\hline HQB 467-z3 - 12 & $x^{*}$ & 1940 & 106 & 18.4 & 1191 & 62 & 354 & 94.64 & 0.515 & 0.019 & 0.0674 & 0.0012 & 0.194 & 421 & 8 & 99.5 \\
\hline HQB 467-z3 - 3 & $\mathrm{x}$ & 313 & 20 & 15.8 & 182 & 17 & 273 & 93.23 & 0.536 & 0.062 & 0.0707 & 0.0014 & 0.632 & 440 & 8 & 103.4 \\
\hline HQB 467-z3 - 5 & $x^{*}$ & 435 & 26 & 16.5 & 284 & 41 & 295 & 93.73 & 0.522 & 0.039 & 0.0678 & 0.0015 & 0.511 & 423 & 9 & 99.6 \\
\hline HQB 467-z3 - 6 & $x^{*}$ & 863 & 46 & 18.9 & 279 & 37 & 711 & 97.7 & 0.506 & 0.023 & 0.0680 & 0.0011 & 0.382 & 424 & 7 & 102.5 \\
\hline HQB 467-z3 - 7 & $x^{*}$ & 982 & 49 & 20.2 & 307 & 39 & 778 & 97.88 & 0.505 & 0.031 & 0.0683 & 0.0012 & 0.348 & 426 & 8 & 102.3 \\
\hline HQB 467-z & $\mathrm{x}$ & 547 & 39 & 14 & 302 & 20 & b & 97.12 & 0.524 & 0.033 & 0.06 & 0.0013 & 0.381 & 429 & 8 & 100.2 \\
\hline HQB 467-z3 - 9 & & 4483 & 188 & 23.8 & 6 & 14 & 69183 & 99.96 & 0.532 & 0.01 & 0.0695 & 0.0012 & 0.648 & 433 & 7 & 100.1 \\
\hline
\end{tabular}

Notes: $\mathrm{x}=$ common $-\mathrm{Pb}$ corrected using measured ${ }^{204} \mathrm{~Pb} ; \mathrm{a}=$ common $-\mathrm{Pb}$ corrected using the method of_Andersen $(2002) ;{ }^{*}=$ used for concordia calculation; ${ }^{1}$ absolute internal error; ${ }^{2}$ calculated using method from from Andersen (2002); ${ }^{3}$ calculated as $100 \times\left({ }^{206} \mathrm{~Pb} /{ }^{238} \mathrm{U}\right.$ age $/{ }^{207} \mathrm{~Pb} /{ }^{235} \mathrm{U}$ age) 


\section{Olivine $\mathrm{FeO} /(\mathrm{FeO}+\mathrm{MgO})$ values}

Olivine occurs as corroded, anhedral, individual or clusters of cumulus grains, poikilitically included in intercumulus augite (Fig. 5a). At the time of our analytical work on olivine, we had samples of the Baxter and Ritcey headstones, but only five samples from the Hanson quarry. The Baxter headstone and three of the five Hanson quarry samples contain olivine, but the Ritcey headstone and the other two Hanson quarry samples do not. The olivine analyses come from two polished thin sections cut from the Baxter headstone (T-orig and T-87) and two polished thin sections cut from one Hanson quarry sample (104A1 and 104A2) (Table 2). Altogether, we analyzed 11 olivine grains from the Baxter headstone and six olivine grains from the Hanson quarry. Table 2 also shows the number of analytical points for each grain, the mean $\mathrm{FeO} /(\mathrm{FeO}+\mathrm{MgO})$ values for each grain, and the range of $\mathrm{FeO} /(\mathrm{FeO}+\mathrm{MgO})$ values. The range of $\mathrm{FeO} /(\mathrm{FeO}+\mathrm{MgO})$ values from a homogeneous olivine control sample (174.1) is $0.003(\mathrm{n}=15)$, attributed to analytical error, indicating that most of the Baxter and Hanson olivine grains are chemically zoned. Because the olivine grains are anhedral relics, their precise locations in the former originally zoned crystals are unknown.

Figure $5 \mathrm{~b}$ shows the 81 individual determinations of $\mathrm{FeO} /$ $(\mathrm{FeO}+\mathrm{MgO})$ in olivine grains (open circles) and the grain means (filled circles). We used a mixed-effects analysis of variance (Pinheiro and Bates 2013) to compare mean $\mathrm{FeO} /$ $(\mathrm{FeO}+\mathrm{MgO})$ values of olivine grains in the four polished thin sections, with a random effect accounting for the correlation between observations from each grain. A mixedeffects analysis compares the differences in sample means to the between-grain variation, rather than to the withingrain variation. We found no significant difference among the mean $\mathrm{FeO} /(\mathrm{FeO}+\mathrm{MgO})$ values of the olivine grains in the four thin sections using a likelihood ratio test $(\mathrm{P}=0.13)$. There is a large variance component for the grains, which quantifies the large differences among the mean values of the grains apparent in Figure 5b. Three of the five grains in $104 \mathrm{~A} 2$ have high $\mathrm{FeO} /(\mathrm{FeO}+\mathrm{MgO})$ values relative to the other grains, and these analyses are possibly from former rims rather than cores. The relatively large differences between the olivine compositions in two thin sections (104A1 and 104A2) cut from one sample (104A) underscore Murray's cautionary comment quoted in Principle 9 above.

In conclusion, given that olivine $\mathrm{FeO} /(\mathrm{FeO}+\mathrm{MgO})$ values can theoretically range from 0.00 to 1.00 , it is remarkable that the values from the Titanic headstones and Hanson quarry occupy such a restricted part of this compositional spectrum, and that there is no significant difference between the mean olivine compositions in headstones and quarry.

\section{Augite rim trace-element concentrations}

The ideal condition under which to compare mineral compositions is that in which the mineral under investigation shows no chemical zonation. Petrographic examination with crossed-polarized light clearly shows that augite grains of the Titanic headstones and Hanson quarry are optically, and therefore chemically, strongly zoned. Because, in a twodimensional thin section, the three-dimensional cores of grains cannot be determined with any degree of certainty, we can compare only the rims (Principle 4). Figure 6a shows one of the analyzed augite grains from the Baxter headstone, and some of the laser-ablation craters around its rim (arrows), and Table 3 shows the average compositions of the augite rims.

The Appendix contains details of the analytical procedures and data processing. Most importantly, we also analyzed augite grains from two completely unrelated gabbros to test that there is no universal standard composition for augite rims in gabbros, in which case the statistical similarities between Titanic headstones and Hanson quarry would mean nothing in terms of establishing a connection between them. One of these unrelated gabbros is a pristine haplogabbro (HDG) of unknown age or origin, other than it was sold as tiles by Home Depot ${ }^{\mathrm{mm}}$ in about 2011, and the other is from $380 \mathrm{Ma}$ Atwoods Brook gabbro pluton (ABG) in Nova Scotia (Tate and Clarke 1995), which is petrologically similar to the Titanic headstones.

Figure $6 \mathrm{~b}$ shows conventional spider diagrams for seven major and 28 trace elements in the Titanic (THH), Hanson (HQB), HDG, and ABG gabbros to provide a general visual assessment of similarities and differences between the four sample means. The largest differences between Titanic and Hanson are in $\mathrm{Li}$ (8) and $\mathrm{Cr}(11)$. In addition, the REEs (21-34) have slightly greater concentrations in the Hanson augites, but the slope (fractionation) of the REE pattern and Eu (26) anomalies are similar. In contrast, HDG and ABG augite compositions normalized to Titanic show large differences for many elements, including the concentrations and fractionation patterns of the REEs, as well as the Eu anomaly (HDG is negative and ABG is positive relative to Titanic).

The box plots (Fig. 6c, d) provide a better qualitative visual comparison of the Titanic and Hanson augite rims, because they include the variance for each population. As with the spider diagrams, the box plots show small differences between Titanic and Hanson, and larger differences between HDG and ABG relative to Titanic.

To more rigorously assess all differences between Titanic and Hanson augite rims, we computed a likelihood ratio test for each element individually, by comparing the fits of two mixed-model effects models (Pinheiro and Bates 2013), with a random effect for grains accounting for the correlation between measurements within a single grain (Table 4 ). The smallest P-values were 0.0027 for $\mathrm{Mn}$ and 0.0027 for Li. 

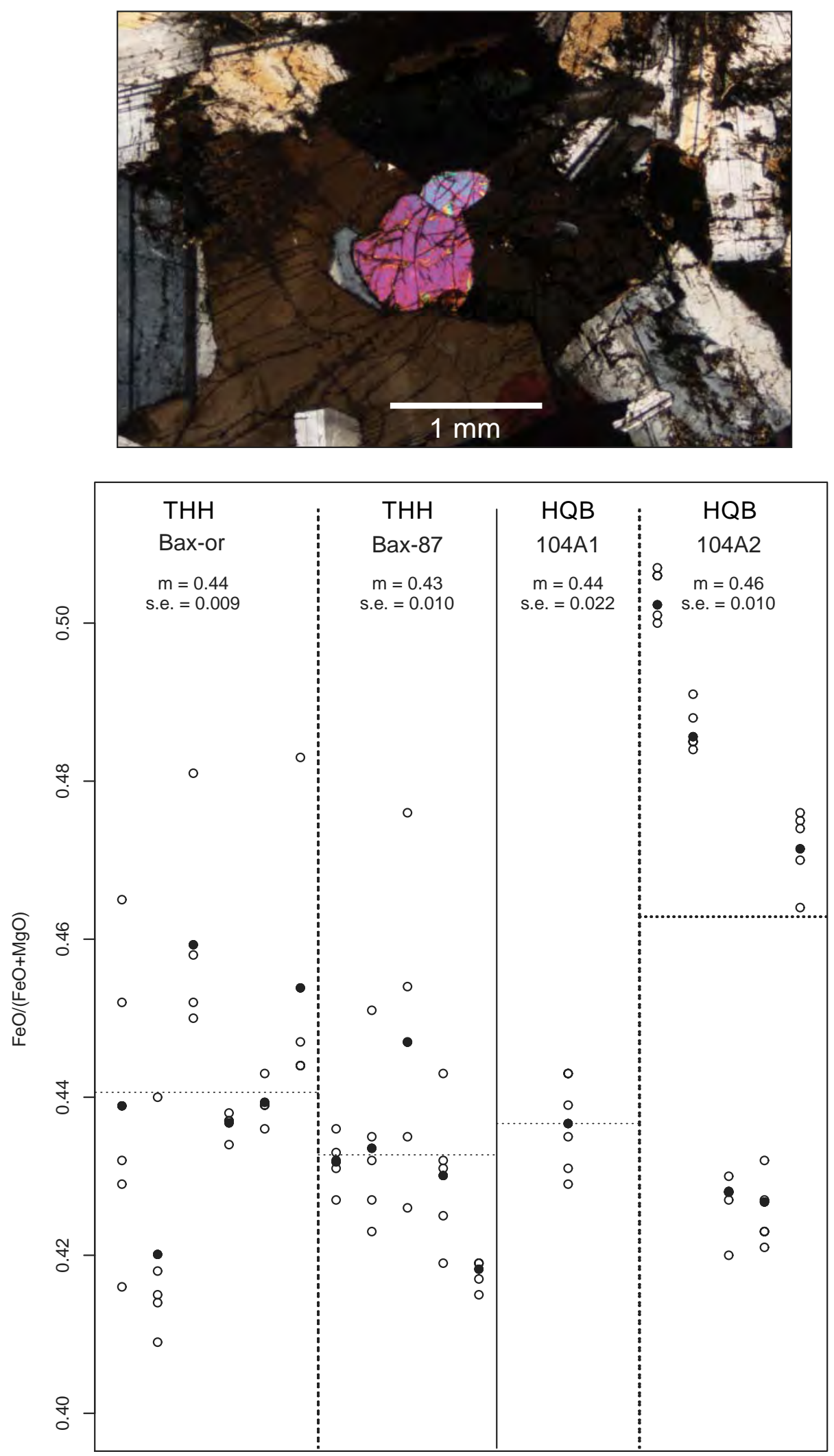

Figure 5. Olivine chemical compositions. (a) Cluster of two, small, corroded olivine grains in the Baxter headstone. (b) All $81 \mathrm{FeO} /(\mathrm{FeO}+\mathrm{MgO})$ analysis points for olivine grains in two polished thin section from the Baxter headstone and in two polished thin sections of sample 104A from the Hanson quarry. Columns of analyses are from single grains; black dot is the single grain mean; dashed line is entire thin section mean. Text for details. 
Table 2. Olivine compositions in two thin sections from the Baxter headstone and two thin sections from Hanson quarry.

\begin{tabular}{lccccc}
\hline & & & & $\begin{array}{c}\text { Mean } \\
\text { F/(F+M) }\end{array}$ & $\begin{array}{c}\text { Range } \\
\text { F/(F+M) }\end{array}$ \\
\hline THH-Bax & T-orig & Gr 2 & 5 & 0.439 & 0.049 \\
& T-orig & Gr 3a & 4 & 0.46 & 0.031 \\
& T-orig & Gr 3b & 4 & 0.436 & 0.003 \\
& T-orig & Gr 3c & 4 & 0.44 & 0.005 \\
& T-orig & Gr 3d & 4 & 0.455 & 0.039 \\
& T-orig & Gr 4 & 5 & 0.419 & 0.031 \\
THH-Bax & T-87 & Gr 1a & 5 & 0.432 & 0.009 \\
& T-87 & Gr 1b & 5 & 0.433 & 0.028 \\
& T-87 & Gr 2 & 5 & 0.448 & 0.05 \\
& T-87 & Gr 3a & 5 & 0.43 & 0.024 \\
& T-87 & Gr 3b & 4 & 0.417 & 0.004 \\
HQB & 104A1 & Gr 1 & 6 & 0.437 & 0.014 \\
& & & & & \\
& 104A2 & Gr 2 & 5 & 0.472 & 0.012 \\
& 104A2 & Gr 2a & 5 & 0.487 & 0.007 \\
& 104A2 & Gr 2b & 5 & 0.504 & 0.007 \\
& 104A2 & Gr 3a & 5 & 0.427 & 0.01 \\
& 104A2 & Gr 3b & 5 & 0.425 & 0.011 \\
\hline
\end{tabular}

Notes: $\mathrm{n}=$ number of analysis points; $\mathrm{F} /(\mathrm{F}+\mathrm{M})=\mathrm{FeO} /(\mathrm{FeO}+$ $\mathrm{MgO})$ ratio; Range $=\left(\mathrm{F} /(\mathrm{F}+\mathrm{M})_{\max }-\mathrm{F} /(\mathrm{F}+\mathrm{M})_{\min }\right)$. Abbreviations: Bax - Baxter headstone, HQB - Hanson Quarry Bocabec, THH Titanic Headstones Halifax.
Using a corrected threshold of $0.05 / 35=0.0014$ for multiple comparisons (Bonferroni 1935), we found no statistically significant differences between Titanic and Hanson augite rims. These findings are remarkable, given that there must be millions of augite grainsin the Titanicheadstones, and billions of augite grains in the Hanson quarry, and yet the chemical compositions for 35 chemical elements from a "random" selection of three grains from the former and two grains from the latter show that they are not statistically different.

However, perhaps the compositions reported here are just some universal standard for augite rims in gabbros, in which case the statistical similarities mean nothing in terms of establishing a connection between the Titanic headstones and Hanson quarry. To at least partly mitigate this problem, we also analyzed 10 spots in the rim of one augite grain from the petrologically similar, but $380 \mathrm{Ma}$, Atwoods Brook gabbro (ABG) from Nova Scotia (Tate and Clarke 1995), and also analyzed 16 spots in the rims of three augite grains from the pristine haplogabbro of unknown age or origin (HDG). Figure 6d also shows the box plots for the augite rim compositions of these unrelated gabbros, and they appear to be different from the compositions of the Titanic and Hanson augite rims. Element-by-element comparison of these two gabbros to the Titanic samples shows statistically significant differences, with 11 ABG elements and 13 HDG elements falling below the Bonferronicorrected threshold of $0.05 / 35=0.0014$. Clearly these two

Table 3. Mean chemical compositions of augite rims in Titanic headstones, Hanson quarry, HDG gabbro, and $A B G$ gabbro.

\begin{tabular}{|c|c|c|c|c|c|c|c|c|c|c|}
\hline & $\mathrm{Na}$ & $\mathrm{Mg}$ & $\mathrm{Al}$ & $\mathrm{Ca}$ & $\mathrm{Ti}$ & $\mathrm{Mn}$ & $\mathrm{Fe}$ & & & \\
\hline MEAN THH $(\mathrm{n}=24)$ & 3289 & 87507 & 19340 & 145800 & 6866 & 1678 & 61067 & & & \\
\hline MEAN HQB $(n=19)$ & 3214 & 88894 & 17987 & 149960 & 7154 & 1803 & 64708 & & & \\
\hline MEAN HDG $(n=23)$ & 1695 & 85813 & 13484 & 94244 & 3762 & 3178 & 140311 & & & \\
\hline \multirow[t]{2}{*}{ MEAN ABG $(\mathrm{n}=17)$} & 7007 & 96874 & 42005 & 89007 & 4302 & 2475 & 86204 & & & \\
\hline & $\mathrm{Li}$ & $\mathrm{Sc}$ & $\mathrm{V}$ & $\mathrm{Cr}$ & Co & $\mathrm{Ni}$ & $\mathrm{Cu}$ & $\mathrm{Zn}$ & $\mathrm{Ga}$ & $\mathrm{Ge}$ \\
\hline MEAN THH $(\mathrm{n}=46)$ & 22.56 & 153.76 & 371.90 & 1287.64 & 38.82 & 88.91 & 0.25 & 41.51 & 7.92 & 2.86 \\
\hline MEAN HQB $(\mathrm{n}=39)$ & 26.78 & 154.33 & 384.87 & 586.82 & 39.06 & 91.69 & 0.23 & 43.93 & 7.61 & 2.79 \\
\hline MEAN HDG $(n=23)$ & 7.03 & 102.12 & 456.80 & 528.73 & 92.87 & 171.70 & 1.24 & 146.31 & 7.32 & 2.85 \\
\hline \multirow[t]{2}{*}{ MEAN ABG $(n=17)$} & 8.71 & 135.22 & 495.58 & 1028.37 & 34.68 & 10.36 & 0.30 & 112.54 & 14.20 & 3.09 \\
\hline & $\mathrm{Sr}$ & $\mathrm{Y}$ & $\mathrm{Zr}$ & $\mathrm{La}$ & $\mathrm{Ce}$ & $\operatorname{Pr}$ & $\mathrm{Nd}$ & $\mathrm{Sm}$ & $\mathrm{Eu}$ & $\mathrm{Gd}$ \\
\hline MEAN THH $(\mathrm{n}=46)$ & 23.19 & 22.73 & 32.95 & 1.32 & 5.35 & 1.11 & 7.46 & 3.11 & 1.12 & 4.33 \\
\hline MEAN HQB $(\mathrm{n}=39)$ & 23.56 & 24.65 & 32.94 & 1.36 & 5.77 & 1.21 & 8.43 & 3.43 & 1.24 & 4.75 \\
\hline MEAN HDG $(n=23)$ & 8.15 & 24.06 & 22.94 & 1.67 & 5.40 & 0.90 & 5.47 & 2.27 & 0.65 & 3.26 \\
\hline \multirow[t]{2}{*}{ MEAN ABG $(n=17)$} & 18.45 & 16.27 & 22.10 & 1.76 & 6.36 & 1.17 & 6.79 & 2.52 & 1.04 & 3.34 \\
\hline & $\mathrm{Tb}$ & Dy & Ho & Er & $\mathrm{Tm}$ & $\mathrm{Yb}$ & $\mathrm{Lu}$ & $\mathrm{Hf}$ & & \\
\hline MEAN THH $(\mathrm{n}=46)$ & 0.73 & 4.53 & 0.93 & 2.44 & 0.32 & 2.15 & 0.29 & 1.55 & & \\
\hline MEAN HQB (n = 39) & 0.78 & 5.03 & 1.02 & 2.61 & 0.35 & 2.24 & 0.32 & 1.54 & & \\
\hline MEAN HDG $(n=23)$ & 0.61 & 4.28 & 0.95 & 2.71 & 0.39 & 2.69 & 0.40 & 1.00 & & \\
\hline MEAN ABG $(n=17)$ & 0.49 & 3.04 & 0.60 & 1.66 & 0.25 & 1.63 & 0.23 & 1.37 & & \\
\hline
\end{tabular}

Notes: All concentrations in ppm. Abbreviations: ABG - Atwoods Brook Gabbro, HDG - Home Depot ${ }^{\text {tax }}$

Gabbro, HQB - Hanson Quarry Bocabec, THH - Titanic Headstones Halifax. 

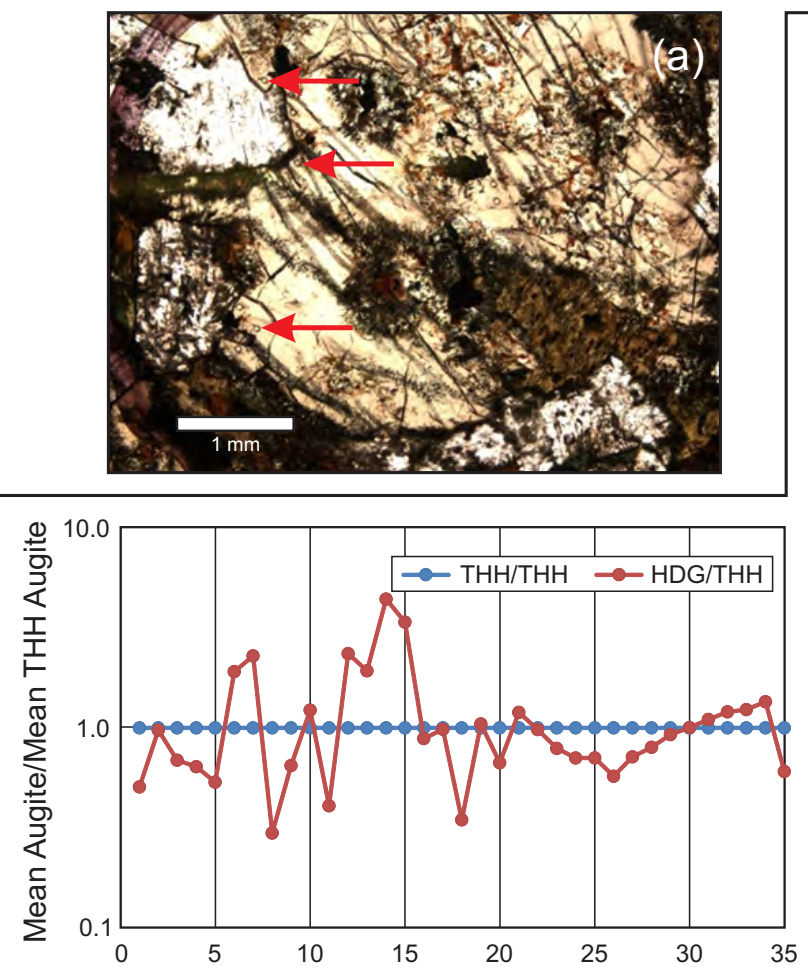

\begin{tabular}{c|l|l} 
Column & \multicolumn{1}{|c|}{ Type } & \multicolumn{1}{c}{ Element } \\
\hline $1-7$ & Major & Na-Mg-Al-Ca-Ti-Mn-Fe \\
\hline 8 & Trace & Li \\
\hline $9-15$ & Trace (Transitional) & Sc-V-Cr-Co-Ni-Cu-Zn \\
\hline $16-20$ & Trace & Ga-Ge-Sr-Y-Zr \\
\hline $21-34$ & Trace (REE) & La-Ce-Pr-Nd-Sm-Eu-Gd-Tb-Dy-Ho-Er-Tm-Yb-Lu \\
\hline 35 & Trace & Hf
\end{tabular}





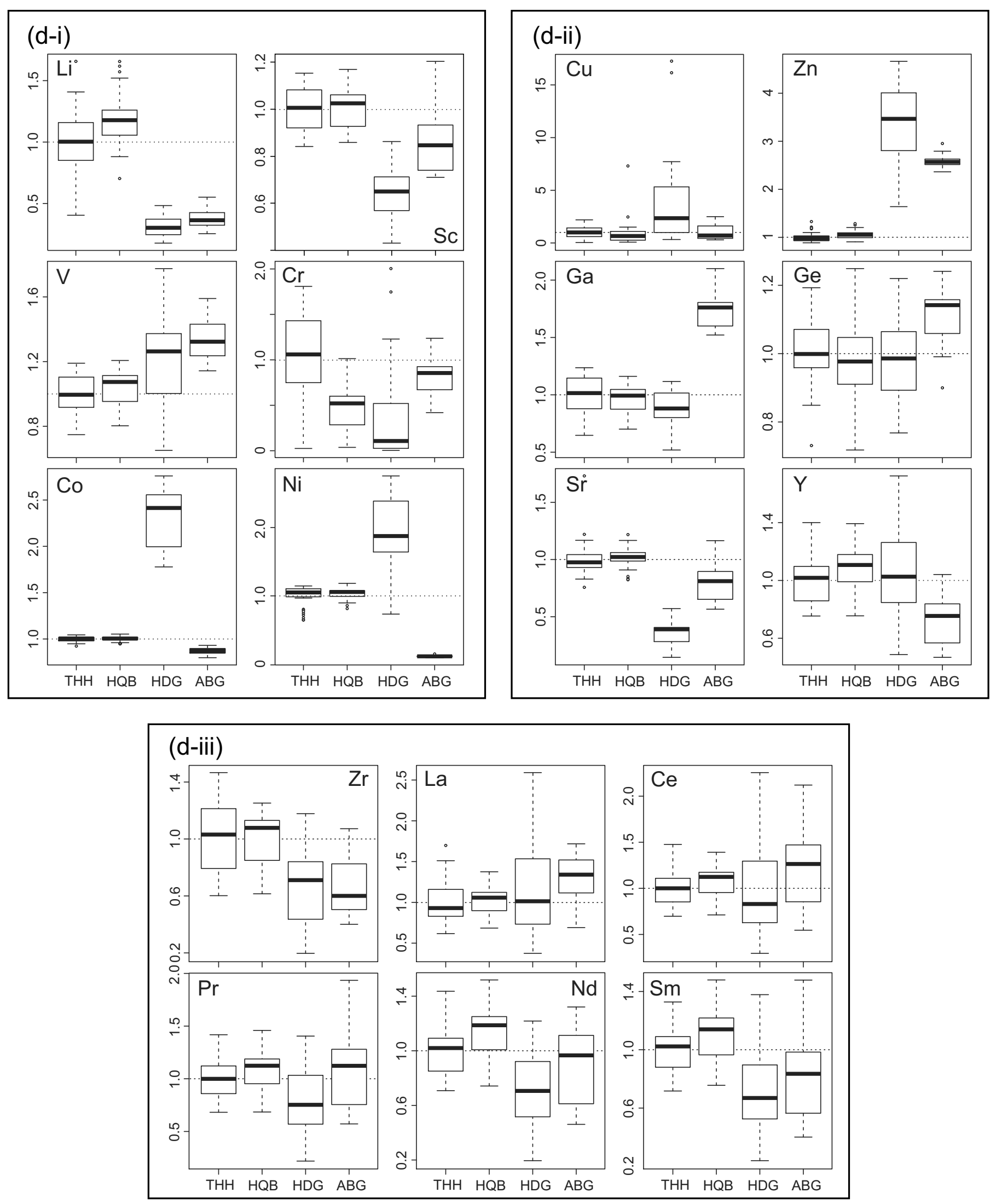

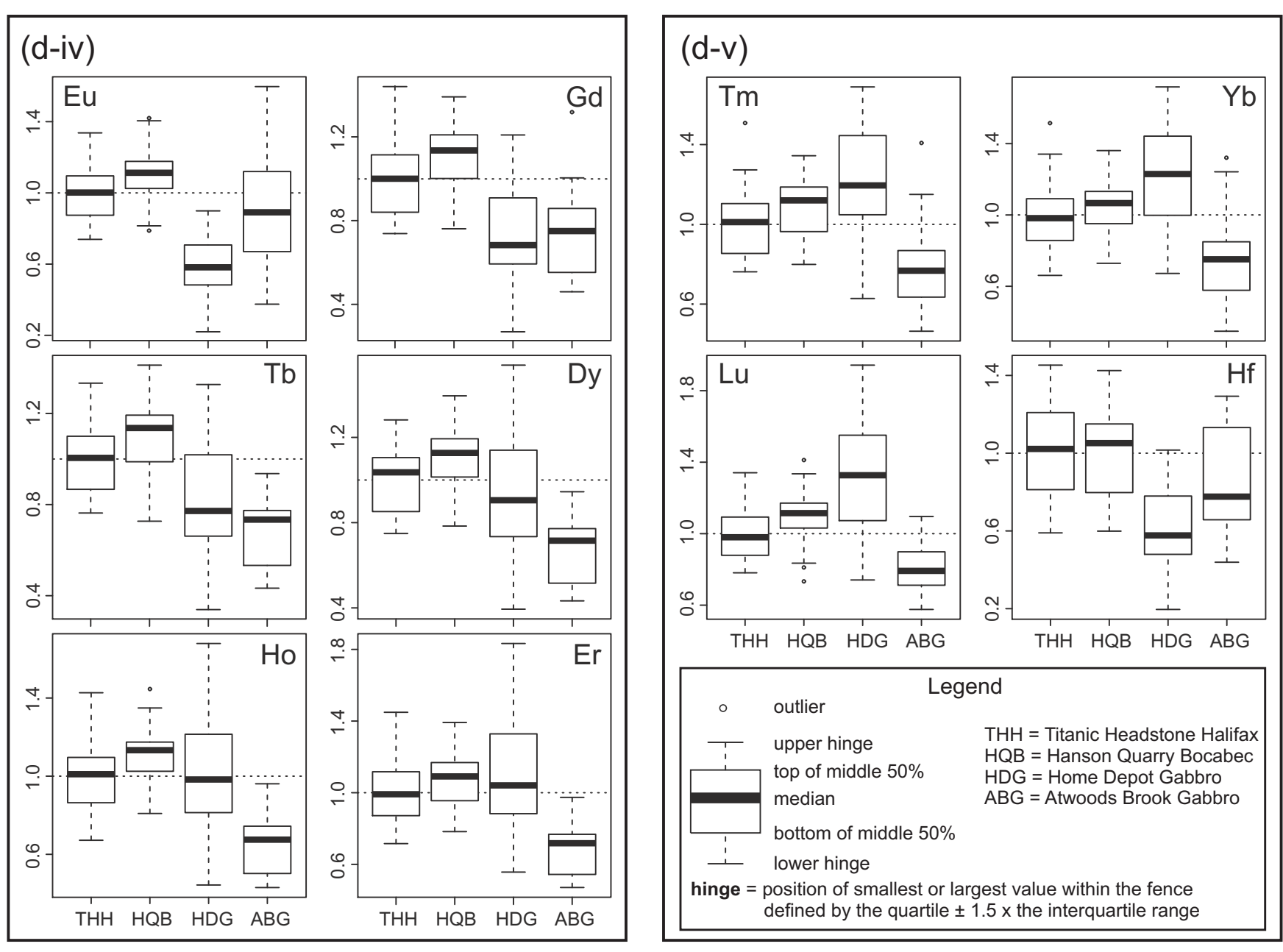

Figure 6. Augite chemical compositions. (a) Augite grain from Baxter Titanic headstone (section Bax-3) in plane polarized light, showing laser ablation craters in the rim (red arrows). (b) Spider diagrams showing the means of Hanson Quarry, HDG gabbro, and MCT gabbro augite rims normalized against mean Titanic augite rims. (c) Box plots for augite rim major-element composition. ( $\mathrm{d}$ i-v) Box plots for augite rim trace-element compositions. THH - titanic headstone, HQB - Hanson quarry, HDG - Home Depot ${ }^{\mathrm{mw}}$ gabbro, ABG - Atwoods brook gabbro. Text for further details.

unrelated gabbro samples have their own distinctive augiterim fingerprints, and this suggests that the good matches between the Titanic and Hanson augite rims are meaningful.

\section{Whole-rock major- and trace-element compositions}

Table 5 shows the concentrations of 10 major elements and 38 trace elements for five rocks from the Baxter and Ritcey headstones, and 12 rocks from the Hanson quarry (two from the walls of the quarry, W464, W467, and the remaining 10 from the abundant fresh angular blocks that were excavated but never removed from the quarry). Of the 12 samples from the quarry, we used the log-ratio distance for unweighted major-element compositional data (Aitchison 1986) to select the three samples (W470d,
W471a, W471b) that are closest to the mean whole-rock chemical composition of the Titanic headstones. The logratio distance is the Euclidean distance between the vectors of elements, transformed by taking the $\log$ of their ratio to $\mathrm{SiO}_{2}$ to eliminate the effect of closure (constant sum).

Figure 7 shows conventional spider diagrams for 48 elements, with the average of the three selected quarry samples normalized to the average of five Titanic samples (with such small populations, box plots are meaningless). For most elements, the mean whole-rock chemical composition of the Hanson quarry shows small differences relative to the mean Titanic headstone composition, with the exceptions of $\mathrm{Cr}$ (14), corresponding to the anomaly that also exists in the augite (Fig. 6b), Cs (24), U (30), and C (49). On the other hand, the bulk chemical compositions of the HDG and ABG 
Table 4. Summary of P-values for augite rim compositions.

\begin{tabular}{|c|c|c|c|c|c|c|c|}
\hline Sample & $\mathrm{Na}$ & $\mathrm{Mg}$ & $\mathrm{Al}$ & $\mathrm{Ca}$ & $\mathrm{Ti}$ & $\mathrm{Mn}$ & $\mathrm{Fe}$ \\
\hline TTH-HQB & 0.6848 & 0.0611 & 0.4213 & 0.0413 & 0.4884 & 0.0027 & 0.0677 \\
\hline TTH-HDG & 0 & 0.3953 & 0.0015 & 0 & 0.0001 & 0 & 0 \\
\hline \multirow[t]{2}{*}{ TTH-ABG } & 0 & 0 & 0 & 0 & 0.0032 & 0 & 0.0002 \\
\hline & $\mathrm{Li}$ & $\mathrm{Sc}$ & V & $\mathrm{Cr}$ & Co & $\mathrm{Ni}$ & $\mathrm{Cu}$ \\
\hline TTH-HQB & 0.0028 & 0.8702 & 0.55 & 0.0119 & 0.6644 & 0.4491 & 0.9852 \\
\hline TTH-HDG & 0 & 0 & 0.003 & 0.0107 & 0 & 0.0001 & 0.102 \\
\hline \multirow[t]{2}{*}{ TTH-ABG } & 0 & 0.0491 & 0.0018 & 0.3499 & 0.0001 & 0 & 0.9085 \\
\hline & $\mathrm{Zn}$ & $\mathrm{Ga}$ & $\mathrm{Ge}$ & $\mathrm{Sr}$ & $\mathrm{Y}$ & $\mathrm{Zr}$ & $\mathrm{La}$ \\
\hline TTH-HQB & 0.0224 & 0.6709 & 0.4596 & 0.8782 & 0.2044 & 0.9684 & 0.7903 \\
\hline TTH-HDG & 0 & 0.1312 & 0.719 & 0 & 0.5114 & 0.0106 & 0.1111 \\
\hline \multirow[t]{2}{*}{ TTH-ABG } & 0 & 0.0001 & 0.0864 & 0.0205 & 0.0078 & 0.0221 & 0.0571 \\
\hline & $\mathrm{Ce}$ & $\operatorname{Pr}$ & $\mathrm{Nd}$ & $\mathrm{Sm}$ & $\mathrm{Eu}$ & Gd & $\mathrm{Tb}$ \\
\hline TTH-HQB & 0.3372 & 0.2301 & 0.0952 & 0.1737 & 0.1331 & 0.1578 & 0.2306 \\
\hline TTH-HDG & 0.8046 & 0.0182 & 0.0017 & 0.0017 & 0.0001 & 0.0012 & 0.0097 \\
\hline \multirow[t]{2}{*}{ TTH-ABG } & 0.0842 & 0.5139 & 0.3859 & 0.0597 & 0.4382 & 0.0127 & 0.0032 \\
\hline & Dy & Ho & Er & $\mathrm{Tm}$ & $\mathrm{Yb}$ & $\mathrm{Lu}$ & $\mathrm{Hf}$ \\
\hline TTH-HQB & 0.1051 & 0.1198 & 0.2646 & 0.1937 & 0.5472 & 0.0906 & 0.9784 \\
\hline TTH-HDG & 0.2881 & 0.9522 & 0.1569 & 0.0422 & 0.0216 & 0.0065 & 0.0019 \\
\hline TTH-ABG & 0.002 & 0.0025 & 0.0032 & 0.0252 & 0.0354 & 0.0083 & 0.2459 \\
\hline
\end{tabular}

Notes: The P-values in italics are those that fall below the threshold of 0.05 ,

indicating significant differences between the populations. Abbreviations: ABG -

Atwoods Brook Gabbro, HDG - Home Depot ${ }^{\text {tw }}$ Gabbro, HQB - Hanson Quarry

Bocabec, THH - Titanic Headstones Halifax.

gabbros appear to have few compositional similarities relative to the Titanic headstones. Clearly, this semi-quantitative, but highly visual, comparison of so many elements together shows that each gabbro has a unique chemical fingerprint.

To more rigorously compare whole-rock chemical compositions of the Titanic headstones and Hanson quarry, we excluded C, and the 10 major elements affected by closure, and used the ANOSIM approach (Anderson 2001) to jointly compare the remaining 37 trace elements. These trace elements are not subject to closure, so we used Euclidean distance instead of the log-ratio distance for this comparison. We also compared the elements individually using t-tests, and Table 6 shows the P-values for all pairs (THH-HQB, THH-HDG, and THH-ABG) and all elements, arranged by geochemical group. For all elements combined, there is no significant difference between the Titanic headstone and Hanson quarry samples [the lowest P-value for any component $\left(\mathrm{Cr}_{2} \mathrm{O}_{3}\right)$ is 0.0141 , whereas the Bonferronicorrected threshold for a significant difference for 37 elements combined is $0.05 / 37=0.0014]$. Table 6 also shows the P-values and Bonferroni-corrected thresholds for LILE, HFSE, REE, TRANS, and OTHER groups of elements. If we apply the Bonferroni (1935) correction for multiple testing, we conclude that even the LILEs in the Titanic headstones and Hanson quarry are not statistically significantly different. If we include the two unrelated gabbros (HDG, $A B G$ ) in the statistical analysis, the test using all 37 trace elements

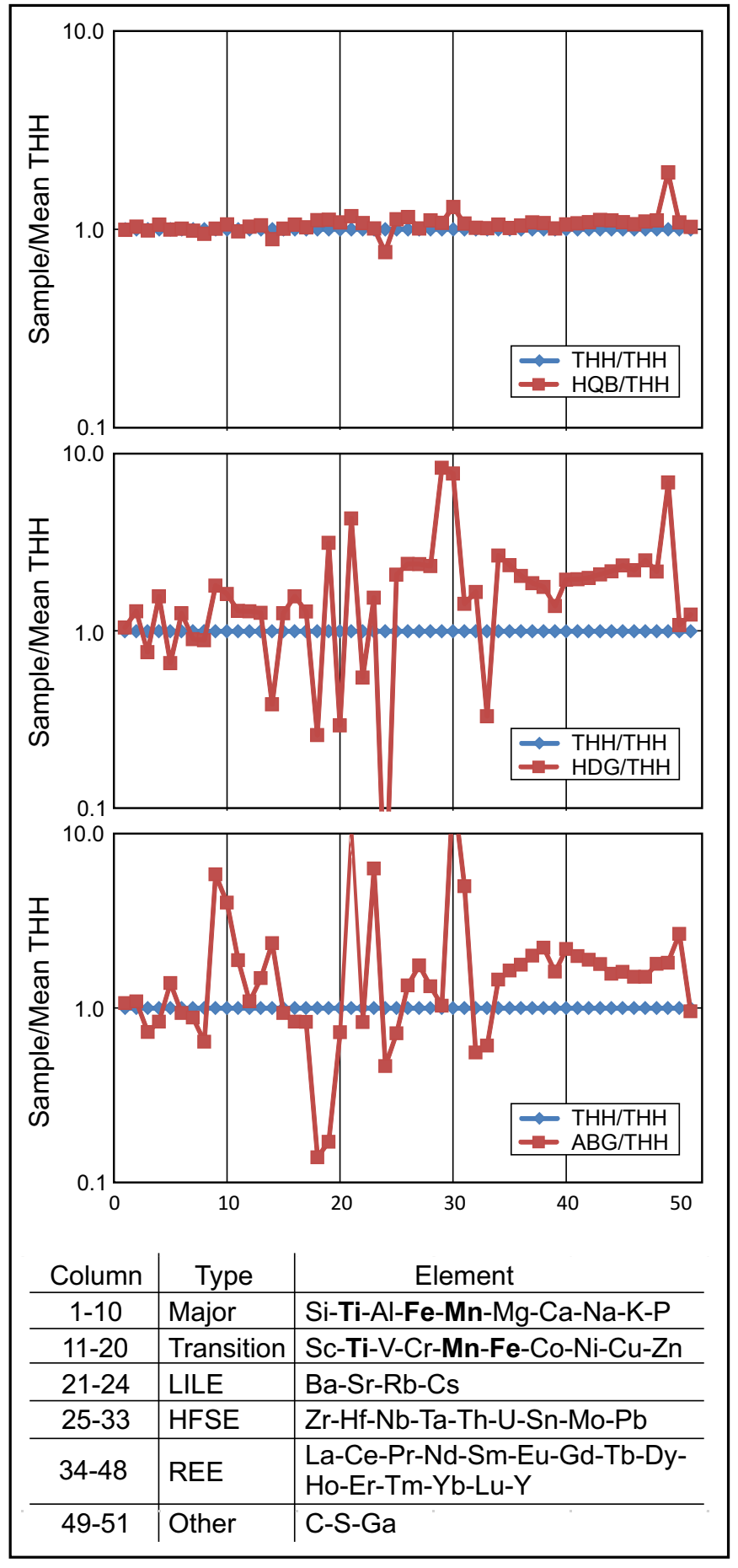

Figure 7. Whole-rock chemical compositions. Spider diagrams for the means of three Hanson quarry samples (W470d, W471a, W471b), one HDG gabbro sample, and one ABG gabbro, normalized to the mean of five Titanic headstone (THH) analyses. (Note that Ti, Mn, and Fe appear twice, as major elements and as transition elements.) For most elements, the Hanson quarry is similar to the Titanic headstones, whereas the HDG and ABG gabbros appear to be different from the Titanic headstones. 
๙ิ)

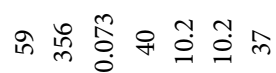

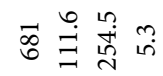

تॄં



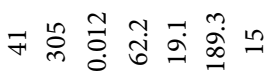





疍突



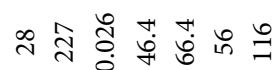

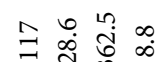

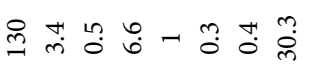

宔 $\underset{3}{\stackrel{4}{3}}$

象

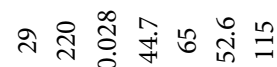

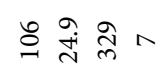

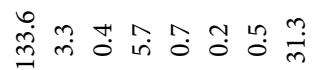

亲突

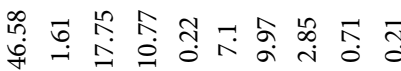

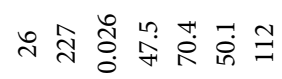

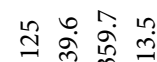

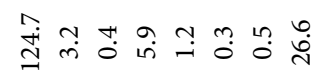

空突

岱

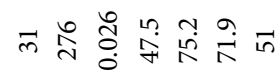

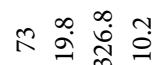

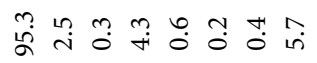

黄贲

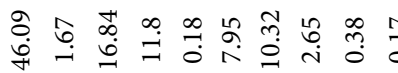

"

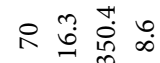

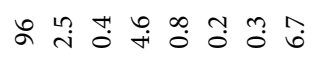

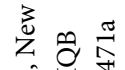

萭

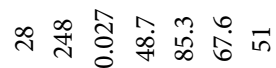

$8 \stackrel{-7}{\stackrel{4}{4}} \stackrel{n}{?}$

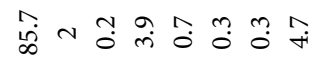

尚



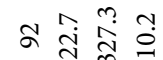

产

辛

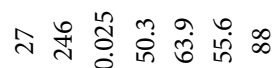

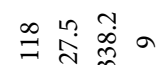

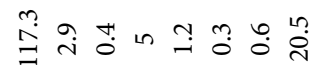

总等

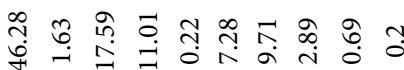

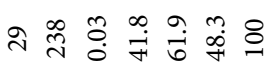

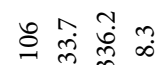

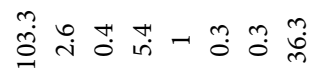

旁莘

भे

तิ

동ํㅇำ

맄 ભ

总草

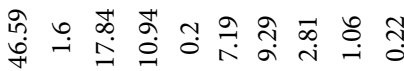

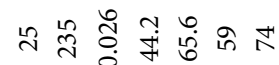



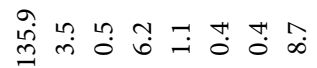

罕

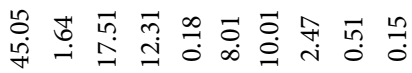

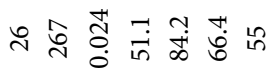

aำ $\stackrel{\ln }{\underset{\sim}{m} \infty}$

लำ

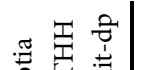

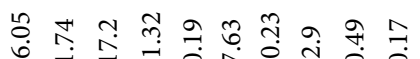



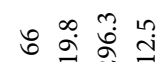

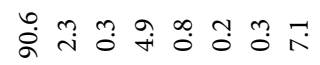

密:

सं

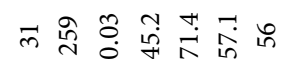

독ำ

紟



๙

in $\stackrel{0}{\circ} \stackrel{\infty}{\dot{\Delta}} \sigma$

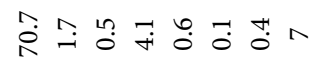

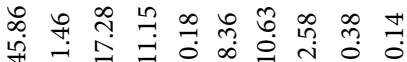

ก สิ

ธ

$\stackrel{0}{\infty} \stackrel{\infty}{\rightarrow}$ 궁

光

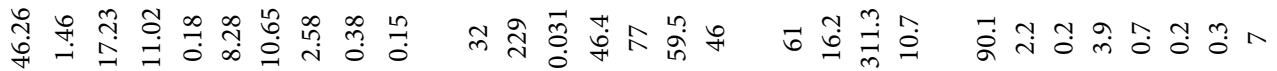

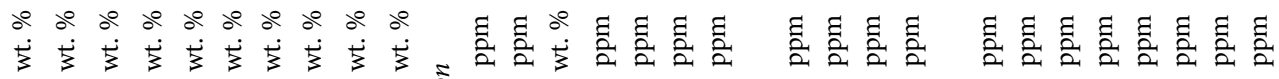

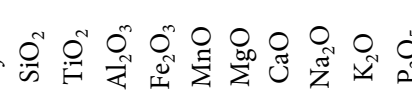

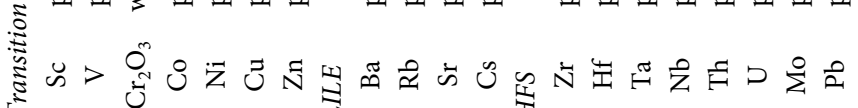


shows many statistically significant $(\mathrm{P}=0.0000)$ differences between Titanic headstones and the two unrelated gabbros.

The $422 \mathrm{Ma}$ gabbros of Maine and bordering New Brunswick are highly differentiated, may even be layered, and are probably co-magmatic with the Bocabec pluton of the Saint George Batholith (McLeod 1990, McLaughlin et al. 2003). If layering is present in the Hanson quarry, it is not evident, perhaps because of the weathering of the walls. It would be easy to show that the ferromagnesianmineral-rich bottoms and felsic-mineral-rich tops of individual rhythmic layers in, for example, the Skaergaard intrusion are statistically unrelated, but such a statistical conclusion would be geological nonsense. So, in the case of the Titanic headstones and Hanson quarry, it is remarkable that the statistical similarity is so good. We expand on this matter of compositional matching in the Discussion.

\section{Summary of quantitative parameters}

In this section, we have presented, visually compared, and statistically tested four largely independent types of quantitative data [zircon ages, olivine $\mathrm{FeO} /(\mathrm{FeO}+\mathrm{MgO})$ values, augite chemical compositions, and whole-rock chemical compositions]. In each case, we have shown that the Titanic headstones and the Hanson quarry populations are not statistically different. Even given that some of these parameters are not entirely independent [e.g., $\mathrm{FeO} /(\mathrm{FeO}+$ $\mathrm{MgO}$ ) in olivine grains vs. $\mathrm{MgO}$ and $\mathrm{FeO}$ concentrations in the whole rocks, or REEs in augite rims and REEs in whole rocks], a strong degree of overlap exists between the two populations for most other parameters (Figs. 4-7). Significant differences do exist for some individual components (e.g., $\mathrm{Cr}$ in augite rims and whole rocks), but these carry little weight for the Bonferroni-corrected entire data set. For those few individual parameters that do not match, we can invoke the caveat mentioned in Principle 10, and reasonably anticipate that more extensive sampling of the quarry would eliminate these anomalies.

\section{SCIENTIFIC QUALITATIVE EVIDENCE}

\section{Primary mineral assemblage}

The primary rock-forming and accessory mineral assemblages, $\mathrm{Pl}+\mathrm{Aug} \pm \mathrm{Ol}+\mathrm{Hbl}+\mathrm{Bt}+\mathrm{Ti}-\mathrm{Mag}+\mathrm{Ap}+\mathrm{Zrn}$ (Whitney and Evans 2010), of the Baxter headstone, Ritcey headstone, and Hanson quarry are identical. A haplogabbro contains augite as its sole ferromagnesian phase, so that these three gabbros contain four primary ferromagnesian phases $(\mathrm{Ol}+\mathrm{Aug}+\mathrm{Hbl}+\mathrm{Bt})$ is sufficiently unusual to be important in establishing a match. What is also important is that some of the other "black granite" quarries in the Saint George Batholith contain prominent primary titanite, a feature of their mineral assemblages that may serve to exclude them as possible sources for the Titanic headstones (Table 7).

\section{Primary modal proportions}

Once the primary mineral assemblage is established, additional similarity depends on the modal proportions of each phase. That all Titanic headstone and Hanson quarry samples are common gabbros, as opposed to, say, troctolites or norites or anorthosites, is essential

Table 6. Summary of P-values for whole-rock compositions in Titanic headstones (THH), Hanson quarry (HQB), Home Depot ${ }^{\mathrm{mix}}$ Gabbro (HDG), and Atwoods Brook Gabbro $(\mathrm{ABG})$.

\begin{tabular}{|c|c|c|c|c|c|c|c|c|c|c|c|c|c|c|c|c|c|}
\hline & \multicolumn{4}{|c|}{ LILE } & \multirow[b]{2}{*}{ BT } & \multirow[b]{2}{*}{$\mathrm{P}<\mathrm{BT}$} & & & \multicolumn{7}{|c|}{ Transition } & \multirow[b]{2}{*}{ BT } & \multirow[b]{2}{*}{$\mathrm{P}<\mathrm{BT}$} \\
\hline & $\mathrm{Ba}$ & $\mathrm{Rb}$ & $\mathrm{Sr}$ & Cs & & & & & $\mathrm{Sc}$ & $\mathrm{V}$ & $\mathrm{Cr}_{2} \mathrm{O}_{3}$ & Co & $\mathrm{Ni}$ & $\mathrm{Cu}$ & $\mathrm{Zn}$ & & \\
\hline THH-HQB & 0.2185 & 0.9394 & 0.0674 & 0.1194 & 0.0125 & 0 & & & 0.5596 & 0.3155 & 0.0141 & 0.7526 & 0.1005 & 0.1436 & 0.3211 & 0.0071 & 0 \\
\hline THH-HDG & 0 & 0.0497 & 0.0005 & 0.0108 & 0.0125 & 3 & & & 0.0006 & 0.0263 & 0 & 0.0909 & 0.0015 & 0.0001 & 0.0044 & 0.0071 & 5 \\
\hline \multirow[t]{3}{*}{ THH-ABG } & 0 & 0 & 0.0174 & 0.0684 & 0.0125 & 2 & & & 0 & 0.0036 & 0 & 0.2733 & 0.0008 & 0.0026 & 0.0868 & 0.0071 & 5 \\
\hline & \multicolumn{8}{|c|}{ HFSE } & \multicolumn{7}{|c|}{ Other } & & \\
\hline & $\mathrm{Zr}$ & $\mathrm{Hf}$ & $\mathrm{Nb}$ & $\mathrm{Ta}$ & $\mathrm{Th}$ & $\bar{U}$ & Mo & $\mathrm{Pb}$ & $\mathrm{BT}$ & $\mathrm{P}<\mathrm{BT}$ & & & $\mathrm{Ga}$ & As & $\mathrm{S}_{\mathrm{Tot}}$ & BT & $\mathrm{P}<\mathrm{BT}$ \\
\hline THH-HQB & 0.1812 & 0.2308 & 0.8976 & 0.7172 & 0.537 & 0.1901 & 0.9132 & 0.9457 & 0.0063 & 0 & & & 0.4224 & 0.9507 & 0.1445 & 0.0167 & 0 \\
\hline THH-HDG & 0.0008 & 0.001 & 0.0006 & 0.0407 & 0 & 0 & 0.0161 & 0.0018 & 0.0063 & 5 & & & 0.0004 & 0.2035 & 0.2663 & 0.0167 & 1 \\
\hline \multirow[t]{3}{*}{ THH-ABG } & 0.0762 & 0.1024 & 0.0063 & 0.4975 & 0.8954 & 0 & 0.056 & 0.0126 & 0.0063 & 1 & & & 0.1326 & 0.2035 & 0 & 0.0167 & 1 \\
\hline & \multicolumn{15}{|c|}{ REE } & & \\
\hline & $\bar{Y}$ & $\mathrm{La}$ & $\mathrm{Ce}$ & $\operatorname{Pr}$ & $\mathrm{Nd}$ & $\mathrm{Sm}$ & $\mathrm{Eu}$ & $\mathrm{Gd}$ & $\mathrm{Tb}$ & Dy & Ho & $\mathrm{Er}$ & $\mathrm{Tm}$ & $\mathrm{Yb}$ & $\mathrm{Lu}$ & BT & $\mathrm{P}<\mathrm{BT}$ \\
\hline THH-HQB & 0.1481 & 0.4763 & 0.8529 & 0.6044 & 0.3864 & 0.437 & 0.8764 & 0.4936 & 0.394 & 0.1966 & 0.2744 & 0.1467 & 0.2471 & 0.5387 & 0.2589 & 0.00333 & 0 \\
\hline THH-HDG & 0.0003 & 0.0001 & 0.0002 & 0.0004 & 0.001 & 0.0021 & 0.0072 & 0.0007 & 0.0008 & 0.0001 & 0.0016 & 0.0001 & 0.0001 & 0.0006 & 0.0002 & 0.00333 & 11 \\
\hline THH-ABG & 0.0015 & 0.0073 & 0.0029 & 0.0012 & 0.0006 & 0.0004 & 0.0013 & 0.0003 & 0.0007 & 0.0001 & 0.0054 & 0.0012 & 0.0028 & 0.014 & 0.0112 & 0.00333 & 11 \\
\hline
\end{tabular}


Table 7. Data for the 16 "black granite" quarries in SW New Brunswick. For one or more reasons (lithology, modal proportions of minerals, textural features, degree of alteration, homogeneity, location of quarry, size of quarry, date of operation of quarry) many candidate quarries are not suitable matches for the Titanic headstones.

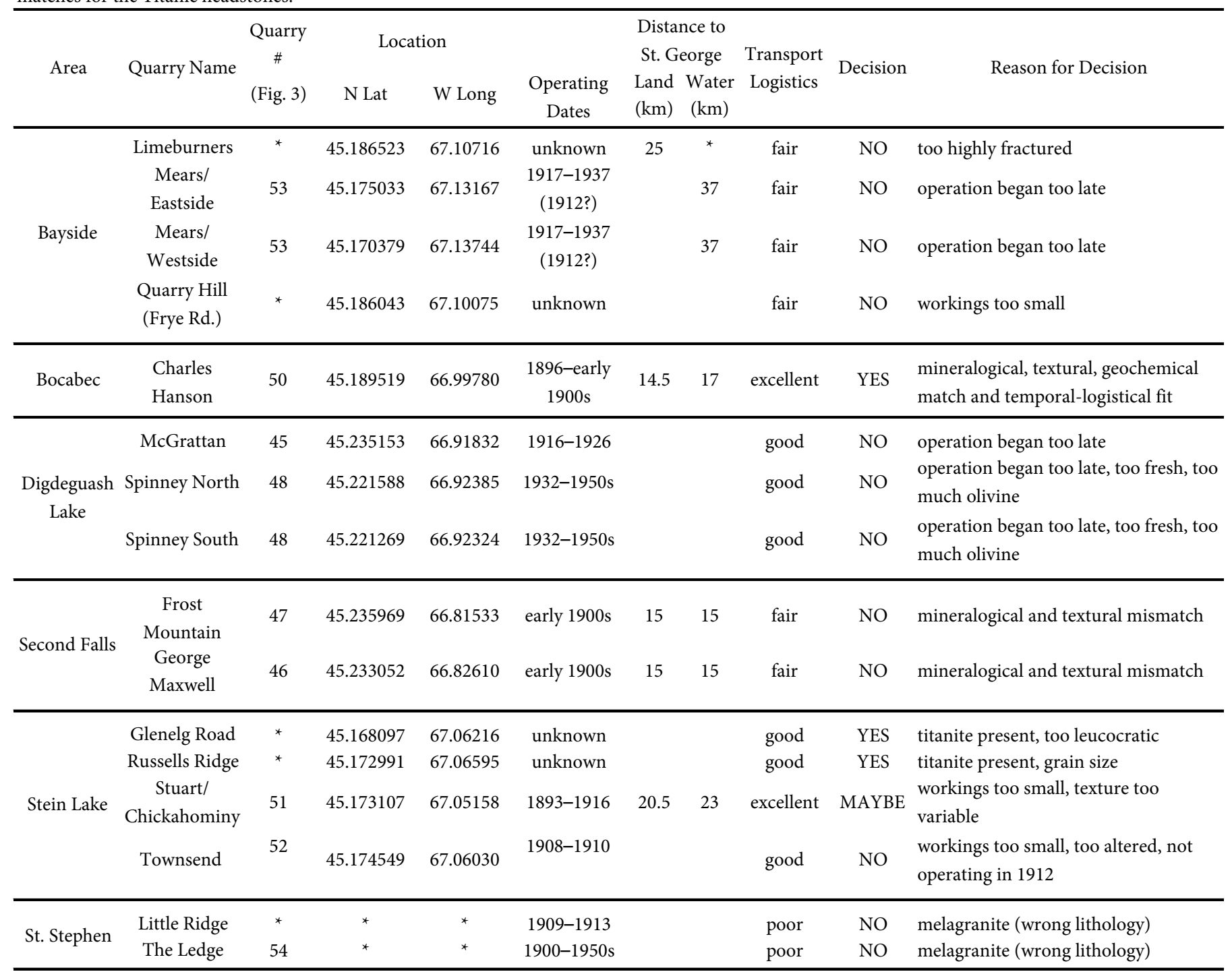

but not particularly useful in making the case for a match. Additionally, the modal proportion of olivine in the Titanic headstones and Hanson quarry ranges from $0-1 \%$, unlike some of the other gabbro quarries in southwestern New Brunswick (e.g., Spinney), which consistently have much higher modal abundances of olivine.

\section{Primary igneous texture}

Thetexturalfingerprint ofanigneous rockinvolves a unique combination of grain sizes, grain shapes, grain orientations, and relationships among grains. All Titanic headstone and Hanson quarry samples are uniformly medium-grained $(1-5 \mathrm{~mm})$. The most striking macroscopic textural feature of all these gabbros is the random orientation of the euhedral plagioclase laths ("snowflake" texture; Holt 2000) (Fig. 1b). At the microscopic level, all Titanic headstone and Hanson quarry rocks have a cumulate texture, with cumulus grains of olivine, plagioclase, and titaniferous magnetite, and large intercumulus grains of augite (Fig. 8a). Furthermore, the corroded anhedral olivine is poikilitically enclosed in augite (Fig. 8b). Although many moderately potassic olivine-bearing gabbros contain prominent apatite prisms, the Titanic headstone and Hanson quarry samples all contain fine-grained anhedral apatite, located along grain boundaries or as inclusions in plagioclase (Fig. 8c, d). Finally, the cumulus titaniferous magnetite grains in all samples commonly have irregular composite reaction rims of hornblende and biotite (Fig. 8e). 
Baxter Headstone

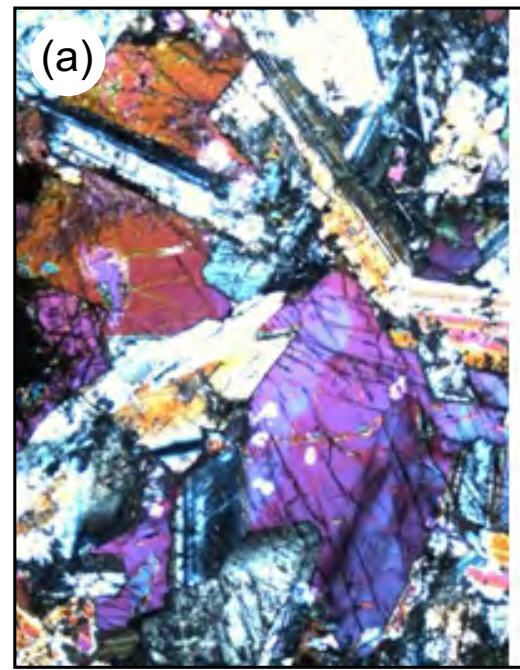

Ritcey Headstone
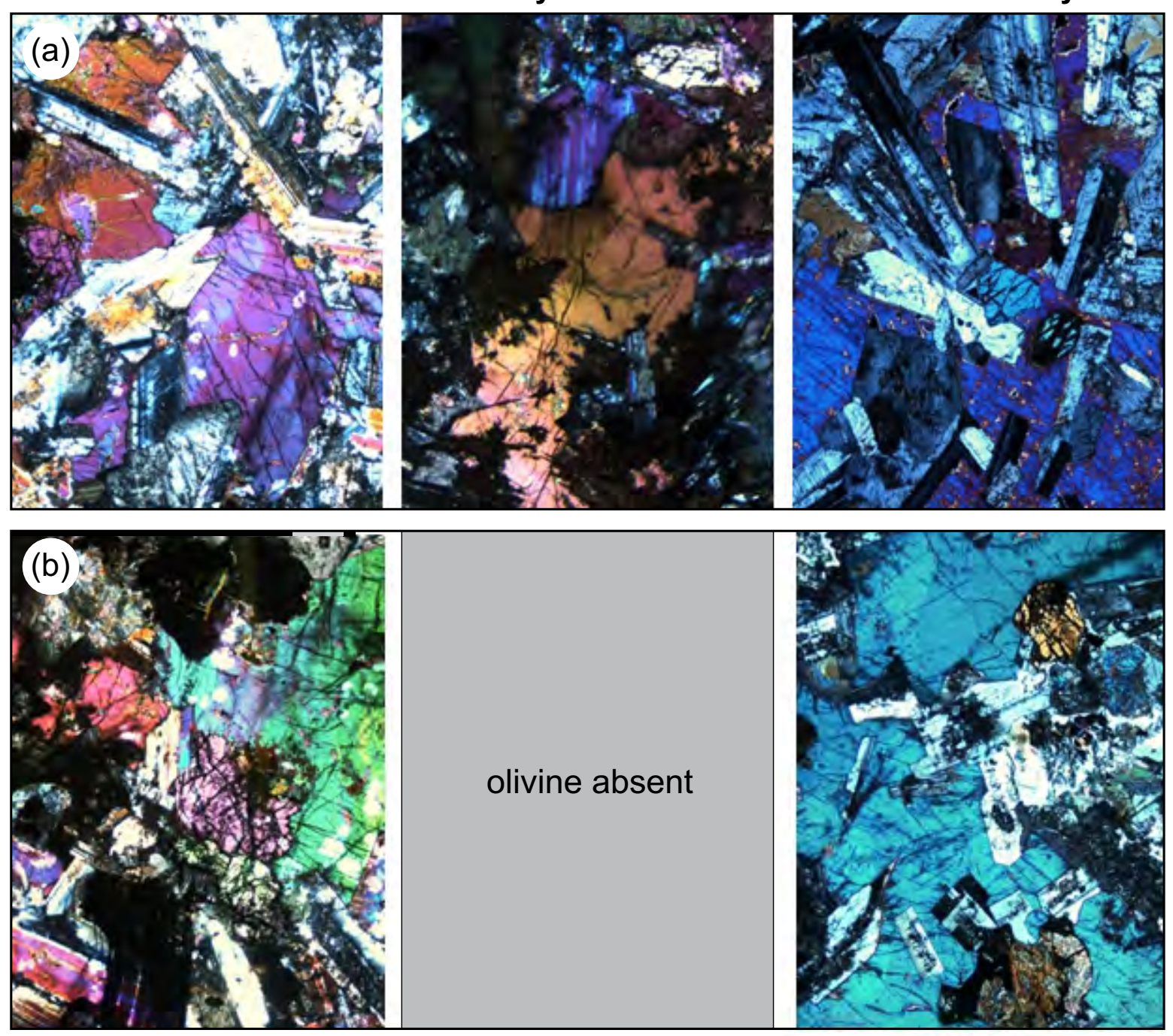

Hanson Quarry
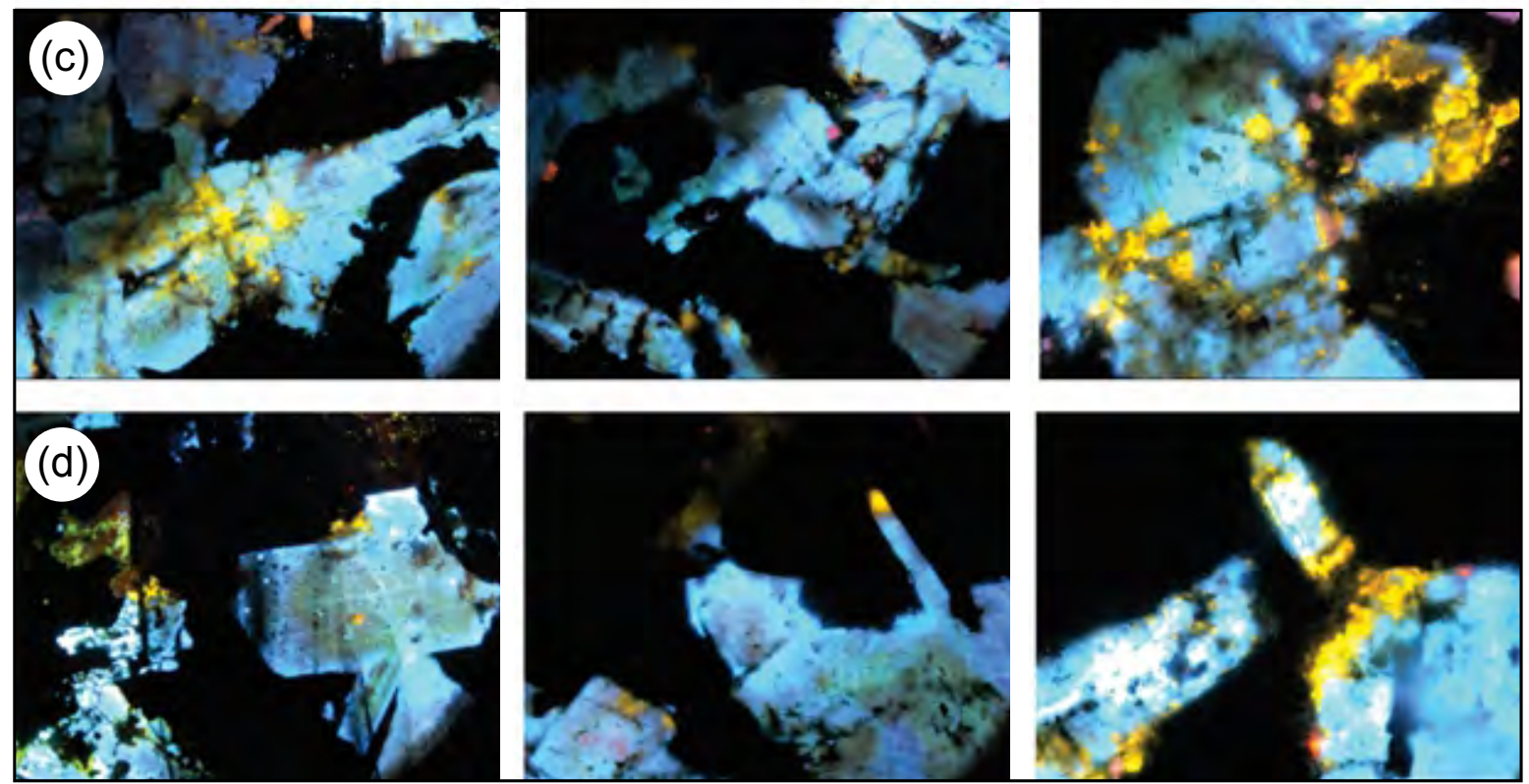
Baxter Headstone
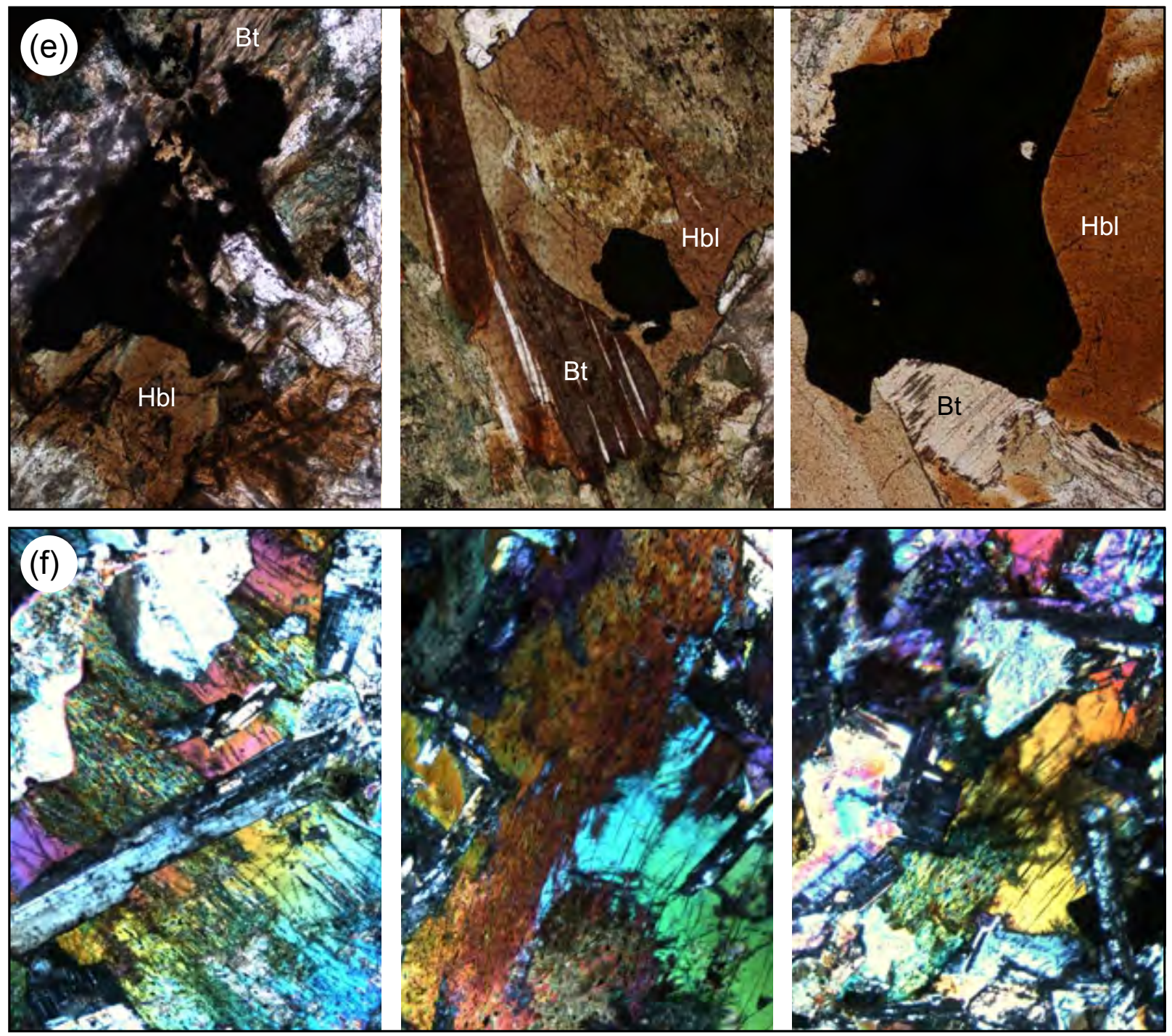

Figure 8. Textures in Baxter, Ritcey, and Hanson gabbros. (a) Randomly oriented cumulus plagioclase crystals partially enclosed by intercumulus augite. FoV $10 \mathrm{~mm}$. (b) Corroded anhedral olivine enclosed in augite. Olivine absent from Ritcey headstone. FoV $10 \mathrm{~mm}$. (c and d) Cathodoluminescence images of small anhedral apatite (yellow) enclosed in, or along grain boundaries of, plagioclase. (e) Titaniferous magnetite with irregular composite reaction rims of hornblende and biotite. FoV $2 \mathrm{~mm}$. (f) Uralite (actinolite) partially replaces primary augite in all samples. FoV $10 \mathrm{~mm}$.

\section{Secondary mineral assemblage}

The secondary alteration minerals, muscovite + chlorite + actinolite, are identical in the headstone and quarry populations, and only the degree of alteration varies somewhat from one sample to another. Furthermore, the degree of alteration in other candidate quarries varies widely from fresh (Spinney) to strongly altered (Townsend), rendering them unsuitable matches for the Titanic headstones on the basis of their degree of alteration alone.

\section{Secondary mineral texture}

Muscovitealteration of plagioclaseand chloritealteration of ferromagnesian minerals in all headstone and quarry samples is unremarkable, but the distinctive partial replacement of augite by actinolite (Fig. 8f) is more unusual, and strengthens the ties between the Titanic headstones and Hanson quarry. 


\section{Summary of qualitative parameters}

In this section, we have presented and compared primary mineral assemblages, secondary mineral assemblages, primary textures, and secondary textures in the Titanic headstones and Hanson quarry. Although there are no statistical tests, according to Principles 3 and 9 , the greater the number of qualitative parameters shared by the Titanic headstones and Hanson quarry, the greater is the probability that they are the same rock.

\section{NON-SCIENTIFIC CIRCUMSTANTIAL EVIDENCE}

\section{Reputation of St. George}

From approximately 1870 to 1940, St. George, New Brunswick, had a reputation as "The Granite Town". At its peak of production, as many as six companies, cutting and polishing dimension stone, operated along the banks of the Magaguadavic River (Martin 2013). As many as 50 quarries intermittently supplied a wide variety of red, pink, and grey granite, as well as "black granite" (gabbro), to these monument companies. An examination of the obituaries in the St. Croix Courier, the St. Andrews Beacon, and the Granite Town Greetings shows a mortality rate in surrounding Charlotte County on the order of one person per day, meaning a local demand for about 180 headstones in a six-month period. If, against this level of demand, came an order from the White Star Line for an additional 150 headstones over a similar six-month period, the source quarry and monument company (or companies) needed to have access to enough material, and have the manufacturing capacity, to be able to accommodate this sudden increase in demand. On the question of availability of material, a rough estimate shows that the total volume of the Titanic headstones constitutes only about $1 \%$ of the excavated volume of the Charles Hanson quarry. On the question of manufacturing capacity, the simple standard chisel shapes of most of the Titanic headstones (Fig. 1), and polishing of only two surfaces (top and front), speaks either to economy (the White Star Line was infamously parsimonious) or haste (delivery of the headstones to Halifax began six months after the Titanic sank), or both.

\section{Operational dates of quarries}

According to Principle 7, any gabbro quarry operating during, or before, 1912 is a possible source for the Titanic headstones, whereas any quarry that opened after 1912 is not possible. If the historical record of operation is correct, at least five of the fourteen truly gabbroic quarries did not exist in 1912 (Table 7). With respect to the Charles Hanson quarry specifically, "The owners of the black granite quarry at Bocabec will commence the construction of their works as soon as the necessary arrangements can be made." (St. Croix Courier, January 11, 1894). In 1906, Henry McGrattan \& Sons took over operation of the "black granite" quarry in Bocabec and built a scow to transport rock to St. George. A year later, the company was actively promoting this material: "Due respect for our departed loved ones demands that we erect not only Artistic but Enduring Memorials. ... Granite is everlasting and our Egyptian Black Granite is far more Artistic and Expressive than any other granite." (Advertisement in Granite Town Greetings, December 4, 1907). Holt (2000) recorded the following: "Down over the Hill, just near Hiram Hanson and beside Bocabec River, was an Agricultural Hall where Fairs were held. My great aunt took me there in the fall of 1893.... Across the Upper Bocabec Bridge, a road led to a granite quarry on land belonging to Charles, son of Hiram Hanson. This quarry was operating in 1908-1909 (I'm sure of this). Another black granite was on the Sam Orr property in lower Bocabec. The Black granite is all over this part of Bocabec." Thus, the Hanson quarry appears to have been well established, and its products actively marketed as Egyptian Black, before 1912.

\section{Local transportation}

All gabbro quarries had transportation routes of various degrees of difficulty to St. George, some overland, some by inland lakes and rivers, and others by sea. According to Principle 8, all other factors being equal, an actively operating gabbro quarry with the easiest transportation route to St. George might be the most likely to have supplied the Titanic headstone material. Table 7 also shows the straight-line distance of each quarry to St. George, and whether that route was primarily by land or by water. Given the primitive state of roads in 1912, water routes were logistically easier than land routes, and saltwater routes more reliable yearround than freshwater routes. These sorts of considerations make the Hanson and Chickahominy quarries highly probable sources for the Titanic headstone material. The transportation logistics criterion is, however, only relative, because all those quarries did send dimension stone to St. George at one time or another, regardless of the difficulty.

\section{Regional transportation}

The Great Southern Railway began service to St. George in 1882 . In 1889, the Great Southern became the Shoreline Railroad, and in 1911 it became part of the Canadian Pacific Railroad. Connections east to Moncton, and south to Halifax on the Intercolonial Railway, later to become Canadian National Railways, also were in operation at this time, and this transportation corridor would have made for quick and easy shipment of dimension stone from St. George to Halifax. In this case, it would not be 
surprising to also find true granite headstones from the Saint George Batholith in Halifax cemeteries. The Mount Olivet Cemetery in Halifax appears to contain gabbros from the Saint George Batholith (in addition to the 19 Titanic headstones that are already there), and a wider survey of Halifax cemeteries may show even more dimension stone with sources in southwestern New Brunswick.

\section{McGrattan marker}

Sometime in 1913, the year following the sinking of the Titanic, and after at least the initial delivery of the headstones to Halifax, John McGrattan, operator of the Charles Hanson quarry in Bocabec, donated a marker (Fig. 9a) to the New Brunswick Museum in Saint John (inscribed as H. McGrattan \& Sons, and catalogued as NBME 1103). Although we have no petrographic, geochemical, or geochronological data for this stone, this marker is a good macroscopic textural match for the Titanic headstones (Fig. 9b). The McGrattan marker also bears a striking morphological and textural resemblance to the generic "Mother" and "Father" markers in the Rural Cemetery in St. Stephen. The question is: why did John McGrattan donate this particular specimen to the New Brunswick Museum and at this particular time? Presumably it was not a common occurrence for quarry operators to donate samples of their products to the Museum. Two possible answers are that this specimen may have been part of a display of New Brunswick dimension stones for participants in an International Geological Congress field trip to the Museum in 1913, or that it was a sample of the Titanic headstones, or both. Future forensic petrological work may yet link the McGrattan marker to the Charles Hanson quarry.

\section{Summary of circumstantial evidence}

At the turn of the $20^{\text {th }}$ Century, St. George had a wellearned reputation as "The Granite Town", supplied by many quarries. In 1912, the operationally and logistically easiest of the "black granite" quarries was the Charles Hanson quarry. The monument works in St. George had the capacity to handle a large order in a relatively short period of time, and also had a well-established rail network to more distant markets. All these circumstantial lines of evidence point to St. George in general, and/or the Charles Hanson quarry in particular, as a reasonable source of the Titanic headstones in Halifax. Although the enigmatic H. McGrattan \& Sons marker in the New Brunswick Museum may be an intriguing clue linking the headstones and the Charles Hanson quarry, what is critically missing is any historical document to support the many lines of scientific and circumstantial evidence.


Figure 9. McGrattan marker. (a) The enigmatic $30-\mathrm{cm}$ long McGrattan marker in the New Brunswick Museum, St. John. (b) Comparison of the macroscopic texture of the Ritcey headstone and the McGrattan marker. Scale units are in $\mathrm{cm}$.

\section{DISCUSSION}

\section{Narrowing the search}

Table 8 illustrates how each of the four essential and diagnostic characteristics of the Titanic headstones served to reduce the search area for the source quarry. Principle 2 helped to locate the geological region of Maine and southwestern New Brunswick, Principle 5 narrowed the search to southwestern New Brunswick, and Principle 6 helped tolocate the possible source quarries. The probabilities in the final column conservatively assume: that all ages from 0 to $4 \mathrm{Ga}$ are equally represented in the continental crust of 
Table 8. Summary showing how each of the four key parameters of the rocks conservatively reduces the probability that the Titanic headstones and Hanson quarry could be so similar but unrelated.

\begin{tabular}{|c|c|c|}
\hline Parameter & Function & Probability Reduction \\
\hline 1. Age & $\begin{array}{l}\text { Assuming that all rock ages from } 4000 \mathrm{Ma} \text { to } 0 \mathrm{Ma} \text { are equally probable, the } \\
\text { probability of any random rock matching an age of } 422 \pm 4 \mathrm{Ma}\end{array}$ & $1.000 \rightarrow 0.002$ \\
\hline 2. Minerals & $\begin{array}{l}\text { Assuming that } 5 \% \text { of rocks on Earth are gabbro, the probability of that } 422 \pm 4 \\
\text { Ma rock matching a gabbro }\end{array}$ & $0.002 \rightarrow 0.0001$ \\
\hline 3. Texture & $\begin{array}{l}\text { Assuming that } 1 \% \text { of all } 422 \pm 4 \text { Ma gabbros have all the distinctive textural } \\
\text { features (e.g., cumulus olivine and oxides, intercumulus augite, apatite } \\
\text { inclusions, oxide reaction rims, etc.) of the Titanic headstones, the probability } \\
\text { of age, lithology, and texture matching }\end{array}$ & $0.0001 \rightarrow 0.000001$ \\
\hline 4. Composition & $\begin{array}{l}\text { Assuming that } 1 \% \text { of all } 422 \pm 4 \text { Ma gabbros with all the distinctive textural } \\
\text { features of the Titanic headstones also having sensibly "the same" } \\
\text { concentrations for } 10 \text { major elements and } 40 \text { trace elements, the probability of } \\
\text { age, lithology, texture, and composition matching }\end{array}$ & $\begin{array}{l}0.000001 \rightarrow 0.00000001 \\
\quad(1 \text { in } 100 \text { million })\end{array}$ \\
\hline
\end{tabular}

the Earth; that gabbros constitute $5 \%$ of continental crust; that $1 \%$ of all $422 \mathrm{Ma}$ gabbros have textures that match the Titanic headstones; and that $1 \%$ of all gabbros with ages, mineralogy, and texture matching the Titanic headstones would also have matching chemical compositions for most elements. If so, the probability that the Titanic headstones and Hanson quarry have so many similar properties, but are completely unrelated, is 1 in 100 million. In fact, the true probability is much less, because we have not included the olivine and augite mineral compositions. In this regard, the highly variable (even in the lithologically restricted range of gabbros) parameters of the age, mineral assemblage, texture, whole-rock chemical composition, and mineral composition are as effective as human DNA in making genetic connections, in this case between the Titanic headstones in Halifax and the Hanson quarry in Bocabec.

\section{Matching the potentially unmatchable}

According to Principle 1, we cannot know the original coordinates of the headstones in their three-dimensional source quarry, because the headstones have been removed and their former location is now marked by a lithological void. Given this condition, one of four scenarios must apply (Fig. 10):

(1) if the source quarry is perfectly homogeneous on a scale larger than the quarry, the headstones, and any other loose quarried blocks, will perfectly match the physical, chemical, and temporal parameters of the quarry walls and floor;

(2) if the source quarry is monotonically variable with horizontal isopleths, the physical and chemical parameters of the headstones will be bounded by these parameters in the walls of the quarry, perhaps even perfectly matched in the walls and loose quarried blocks, and the ages will match precisely;

(3) if the source quarry is monotonically variable with vertical isopleths, the physical and chemical parameters of the headstones will be bounded by these parameters in the floor of the quarry, perhaps even perfectly matched in the floor and loose quarried blocks, and the ages will match precisely;

(4) if the source quarry is irregularly variable, the physical and chemical parameters of the headstones might not match some, or even any, of these parameters in the walls and floor of the quarry, and may match some loose quarried blocks, but the ages will match precisely.

For virtually every quantitative parameter [zircon age, olivine $\mathrm{FeO} /(\mathrm{FeO}+\mathrm{MgO})$ values, augite rim compositions, whole-rock major- and trace-element compositions], we have been able to show that the Titanic headstones and Hanson quarry values are not statistically different, thus an approximation to conditions (2) and (3) above holds, i.e., there is chemical variation in the walls, floor, and blocks of the quarry that almost entirely captures the mineralogical and lithological chemical variation in the headstones. The diagram showing chemical variation for olivine grains (Fig. 5b), as well as the box plots for augite grains (Figs. 6c, d), clearly illustrate this concept. For almost every chemical parameter, at least some overlap exists between the composition of the Titanic headstones and the compositions of material from the quarry.

Of the several scenarios depicted in Figure 10, the case of chemical homogeneity in the quarry and headstones clearly does not apply (Fig. 10a), nor does the case of an absence of compositional overlap between quarry and headstones (Fig. 10d). It is not possible to know precisely where in the spectrum from horizontal to vertical isopleths 
(a)

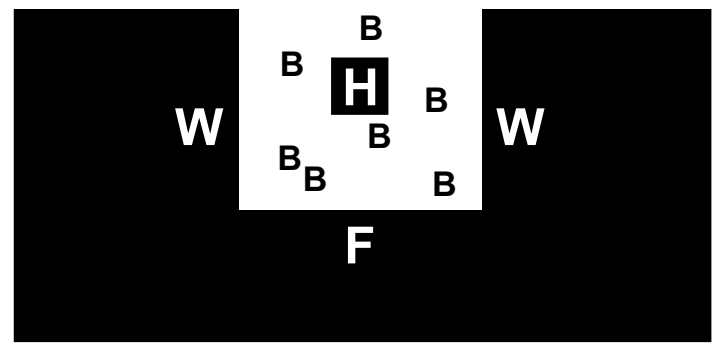

$\mathrm{Q}$ homogeneous (no variation in $\mathrm{W}, \mathrm{F}, \mathrm{B}$, or $\mathrm{H}$ ) no isopleths

$Q$ walls perfectly match $\mathrm{H}$

$Q$ floor perfectly matches $\mathrm{H}$

$\mathrm{Q}$ blocks perfectly match $\mathrm{H}$

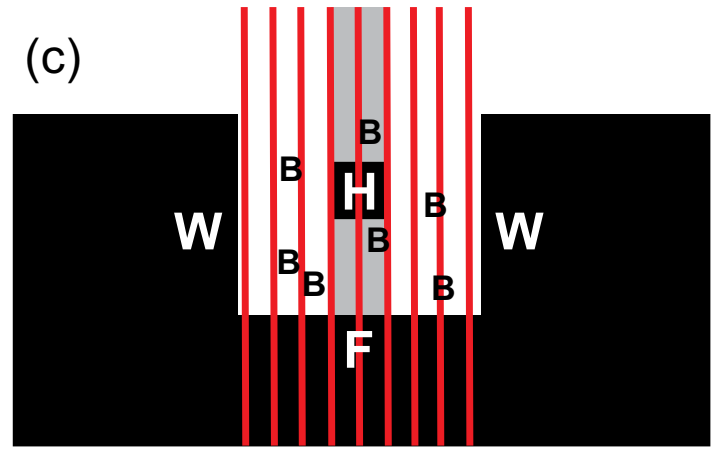

$Q$ heterogeneous

isopleths vertical

$\mathrm{Q}$ walls only bracket range in $\mathrm{H}$

$\mathrm{Q}$ floor perfectly matches and brackets range in $\mathrm{H}$

$\mathrm{Q}$ blocks may match range in $\mathrm{H}$ (b)

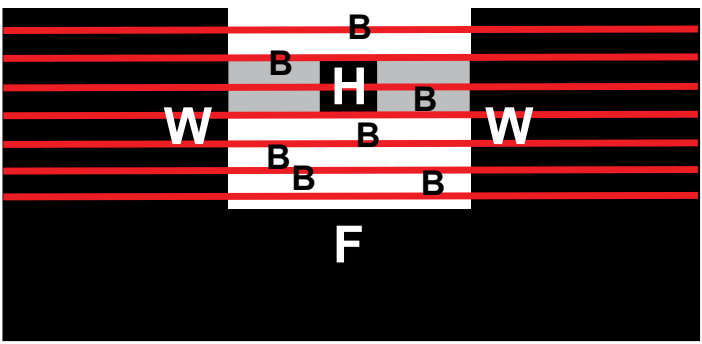

$Q$ heterogeneous

isopleths horizontal

$\mathrm{Q}$ walls perfectly match and bracket range in $\mathrm{H}$

$\mathrm{Q}$ floor perfectly mismatches range in $\mathrm{H}$

$\mathrm{Q}$ blocks may match range in $\mathrm{H}$

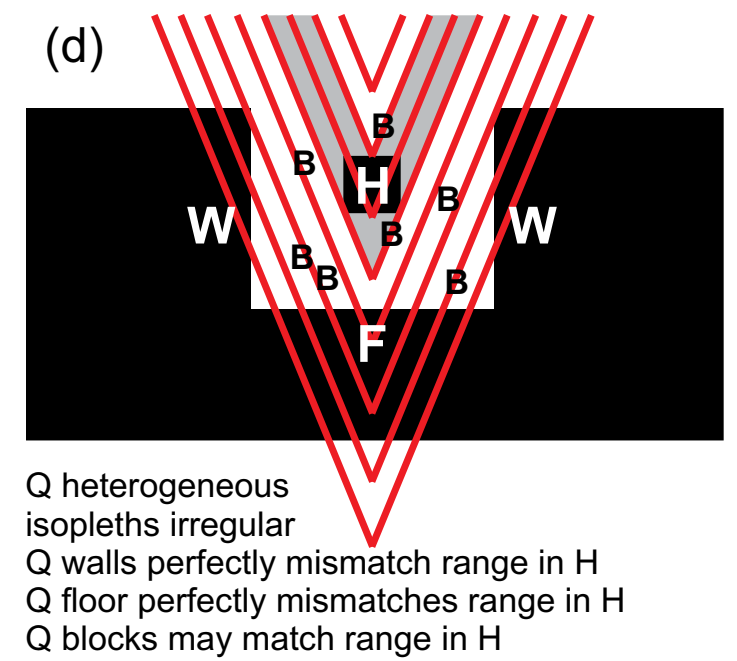

Figure 10. Schematic two-dimensional representation of the relationship between chemical variation in the walls (W), floor (F), and loose quarried blocks (B), of unknown original position in the quarry $(\mathrm{Q})$, relative to chemical variation in extracted headstones $(\mathrm{H})$. Grey shading shows compositional range in $\mathrm{H}$; red lines are isopleths. Where a match between $\mathrm{Q}$ and $\mathrm{H}$ is possible, the goodness of the match depends critically on the number of samples taken of $\mathrm{W}, \mathrm{F}, \mathrm{B}$, and $\mathrm{H}$.

the Hanson quarry lies, but this scenario would seem to apply to the case of the Titanic headstones, with a major caveat. Figure 10d shows the condition in which the walls and floor of the source quarry have no compositional overlap with dimension stone removed from it. This is a low-probability situation, but it is not impossible. Conversely, it is possible that a perfect compositional match between a given quarry and a given dimension stone does not necessarily mean a source-derivative relationship between them. It might mean, however improbably, that another quarry exists with the same matching properties.

In summary, a perfect match between quarry and dimension stone does not necessarily mean a genetic connection, and a perfect mismatch does not necessarily mean the lack of a genetic connection. The statistically good match between Hanson and Titanic leaves open the possibility that another unknown and unnamed quarry exists that is the source of the Titanic headstones. However, of the three types of "black granite" quarries in southwestern New Brunswick, namely known and named, known and unnamed, unknown and unnamed, which type is the most likely to be the source of the Titanic headstones? We invoke Ockham's razor, the law of parsimony, to conclude that a known and named quarry, in this case the Charles Hanson quarry, is more likely to have supplied the large quantity of material for the Titanic headstones than any hypothetical, equally or even better matching, unknown and unnamed quarry. 


\section{Future work}

Several steps could be taken to further test our hypothesis: (1) use a portable XRF instrument to expand our knowledge of the chemical composition of the Titanic headstones;

(2) find a dimension stone that was known for certain to have been sold as "Egyptian Black", and compare it with the Hanson quarry to confirm our deduction that Hanson is the right source quarry for the Titanic headstones;

(3) locate the elusive "lower" quarry at Chickahominy and the "black granite" on the Sam Orr property (Holt 2000), because it is still possible for another quarry to be a better match;

(4) look farther afield to quarries in Memramcook and Welsford to improve confidence

(5) use textural comparisons and a portable XRF instrument to compare the McGrattan marker with the Titanic headstones;

(6) add chemical analyses from the other "black granite" quarries in Table 5;

(7) continue the search for archival documentation to provide historical confirmation of the scientific assessment.

\section{CONCLUSIONS}

In summary, the narrowing of the search for the source of the Titanic headstones involved five discrete steps:

(1) use precise zircon geochronology to select a suitable geological domain;

(2) compare Titanic headstone textures with early $20^{\text {th }}$ Century headstones in cemeteries within that suitable geological domain;

(3) switch to a search for local quarries when the textural matches were found in cemeteries;

(4) establish non-quantitative matching of petrological characteristics (mineral assemblages, textures) of Hanson quarry with Titanic headstones; and

(5) make quantitative statistical comparisons of mineral and whole-rock chemical compositions in the Hanson quarry and Titanic headstones.

According to the Supreme Court of Canada (File 32805, 2008), "(T)here is only one standard of proof and that is proof on a balance of probabilities." We believe that the statistically insignificant differences in the quantitative data (zircon ages, mineral compositions, whole-rock compositions), similar qualitative observations (mineral assemblages, modal proportions, textures), and circumstantial evidence (reputation of St. George, quarrying history, transportation logistics, McGrattan connection) constitute sufficient forensic evidence to show that the Charles Hanson quarry in Bocabec, New Brunswick, is the source of the Titanic headstones in Halifax, Nova Scotia. Any subsequent investigation would have to make a more convincing case for another quarry than we have for the Charles Hanson quarry. Given how different the 13 other gabbro quarries are, the probability that some currently unknown quarry will be a better match than the Hanson quarry is low.

Forensic petrology fundamentally depends on the uniqueness of geological materials. The ranges of ages, mineral assemblages, modal proportions, textures, and chemical compositions are infinite, so that being able to establish quantitative and qualitative identity between two materials from different places (e.g., a crime scene and suspect's possessions or, in this case, headstone and quarry) is tantamount to establishing a connection. The most powerful analytical tool in establishing a connection is the LA ICP-MS, with its capability to determine ages and traceelement concentrations in minerals. We have shown its utility in establishing identity of augite grains, but it could just as easily distinguish between populations of any other mineral.

For students in the Earth sciences, this work underscores the importance of making detailed qualitative descriptions of rocks and minerals, and of making precise quantitative analyses of ages and chemical compositions, to solve petrogenetic problems. The greater the number of matching quantitative and qualitative properties of the Titanic headstones and putative source quarry, the more likely it is that we have found the origin of the headstones. To conclude, in the words of Murray (2004), "When we say 'individualize' or 'having individual characteristics' we mean that the comparison has an extremely high probability of demonstrating that the two samples had a common or mutual source. ... (W)e know from experience and understanding that the possibility of there being another identical sample on this earth is essentially zero."

\section{ACKNOWLEDGEMENTS}

This investigation owes a considerable debt of gratitude to many, including: Alan Ruffman, for drawing our attention to this problem and for facilitating this investigation at several stages during its development; Greg Dunning, of Memorial University, who generously volunteered to provide a TIMS $\mathrm{U}-\mathrm{Pb}$ zircon age on the Baxter headstone that ultimately put our long search for its source on the right geochronological track; the Ritcey family of Riverport, Nova Scotia, for their interest in this work, and for their crucial permission to sample the headstone of A. Susan Ritcey; Susan and Tayvon Clarke for necessary and steadfast assistance in the field; Brandon Boucher, Gordon Brown, Robert MacKay, Dan MacDonald, and Susie Woo for essential assistance in the analytical laboratories; Günter Bäbler of the Titanic Society of Switzerland, Heritage Memorials of Windsor, Nova Scotia, and the Natural Sciences and Engineering Research Council, 
Canada, for financial and in-kind support; colleagues Bill Allan, Sandra Barr, John Drage, Yana Fedortchouk, Les Fyffe, Malcolm Hole, Peter Kokelaar, Dan Kontak, Andrew MacRae, Trevor McHattie, Ian Meighan, Randy Miller, Clint Milligan, Gunter Muecke, Georgia Pe-Piper, Dianne Pothier, Rob Raeside, Peter Reynolds, Ricardo Silva, Brian Upton, Grant Wach, Charlie Walls, Chris White, and Paula Work for scientific consultation and advice; and finally Kathy Bockus, Amberlee Chenard, Jeffery Clarke, Dan Conlin, Jennifer Cormier, Burton Coutts, Doug Dougherty, Tom Duffett, Bill Gardiner, Anita Grearson, Steven Haynes, Michelle Hébert, Susan Johnson, Tracy Lenfesty, Julia Lewandowski, Gwen Martin, Joe McIntosh, Steve Spires, Juanita Sprague, Elizabeth Stevens, Anne Stimers, David Sullivan, and Emily Tracey for their generous assistance in a multitude of ways. We also thank Associate Editor Pietro Vignola for his helpful contributions to the final version of the manuscript. Finally, DBC wishes to acknowledge his mentorship by two of the pillars of the Mineralogical Association of Canada, Len Berry and Ron Graham, when he was a young man learning about mineralogy more than half a century ago.

\section{REFERENCES}

Aitchison, J. 1986. The statistical analysis of compositional data. The Blackburn Press, Caldwell, New Jersey, 416 p. https://doi.org/10.1007/978-94-009-4109-0

Anderson, M. J. 2001. A new method for nonparametric multivariate analysis of variance. Austral Ecology, 26, pp. $32-46$.

Andersen, T. 2002. Correction of common lead in $\mathrm{U}-\mathrm{Pb}$ analyses that do not report ${ }^{204} \mathrm{~Pb}$. Chemical Geology, 192, pp. 59-79. https://doi.org/10.1016/S0009-2541(02) 00195-X

Black, L.P., Kamo, S.L., Allen, C.M., Aleinikoff, J.N., Davis, D.W., Korsch, R.J., and Foudoulis, C. 2003. TEMORA 1: a new zircon standard for Phanerozoic U-Pb geochronology. Chemical Geology, 200, pp. 155-170. https://doi.org/10.1016/S0009-2541(03)00165-7

Bonferroni, C.E. 1935. "Il calcolo delle assicurazioni su gruppi di teste." In studi in onore del professore Salvatore Ortu Carboni. Rome, Italy, pp.13-60.

Holt, A. M. 2000. The memoirs of Annie M. Holt and the people of Bocabec, past and present. URL <http://www. rootsweb.ancestry.com/ nbstpatr/annieholt/AHfulltext .htm> December, 2000.

Kalbfleisch, J. G. 1985. Probability and statistical inference ( $2^{\text {nd }}$ edition). Springer-Verlag, New York, $356 \mathrm{p}$.

Kramers, J.D. and Tolstikhin, I.N. 1997. Two terrestrial lead isotope paradoxes, forward transport modeling, core formation and the history of the continental crust. Chemical Geology, 139, pp. 75-110. https://doi. org/10.1016/S0009-2541(97)00027-2
McLaughlin, K. J., Barr, S. M., Hill, M. D., Thompson, M D., Ramezani, J., and Reynolds, P. H. 2003. The Moosehorn Plutonic Suite, southeastern Maine and southwestern New Brunswick: age, petrochemistry, and tectonic setting. Atlantic Geology, 39, pp. 123-146. https://doi. org/10.4138/1176

McLeod, M. J. 1990. Geology, geochemistry, and related mineral deposits of the St. George batholith; Charlotte, Queens, and Kings counties, New Brunswick. New Brunswick Natural Resources and Energy, Mineral Resources, Mineral Resource Report 5, 169 p.

Martin, G. 2013. The granite industry of southwestern New Brunswick: a historical perspective. New Brunswick Energy and Mines, Popular Geology Paper, 2013-1, 104 p.

Martin, G. L. 1990. For love of stone, volume I, the story of New Brunswick's building stone industry. New Brunswick Department of Natural Resources and Energy, Mineral Resources Division, Miscellaneous Report No. 8, 176 p.

Murray, R. C. 2004. Evidence from the Earth: forensic geology and criminal investigation. Mountain Press Publishing Company, Missoula, Montana, 226 p.

Paces, J.B. and Miller, J.D. 1993. Precise U-Pb ages of Duluth Complex and related mafic intrusions, northeastern Minnesota - geochronological insights to physical, petrogenetic, paleomagnetic, and tectonomagmatic processes associated with the $1.1 \mathrm{Ga}$ midcontinent rift system. Journal of Geophysical Research-Solid Earth, 98(B8), pp. 13997-14013. https://doi.org/10. 1029/93JB01159

Parks, W. A. 1914. Report on the building and ornamental stones of Canada II, Maritime Provinces. Canada Department of Mines, 203, $264 \mathrm{p}$.

Paton, C., Hellstrom, J.C., Paul, B., Woodhead, J.D., and Hergt, J.M. 2011. Iolite: freeware for the visualisation and processing of mass spectrometric data. Journal of Analytical Atomic Spectrometry 26, pp. 2508-2518. https://doi.org/10.1039/clja10172b

Paton, C., Woodhead, J. D., Hellstrom, J. C., Hergt, J. M., Greig, A., and Maas, R. 2010. Improved laser ablation $\mathrm{U}-\mathrm{Pb}$ zircon geochronology through robust downhole fractionation correction. Geochemistry, Geophysics, Geosystems, 11, Q0AA06 doi:10.1029/2009GC002618. https://doi.org/10.1029/2009GC002618

Petrus, J.A. and Kamber, B.S. 2012. VizualAge: a novel approach to laser ablation ICP-MS U-Pb geochronology data reduction. Geostandards and Geoanalytical Research, 36, pp. 247-270. https://doi.org/10.1111/j.1751908X.2012.00158.x

Pinheiro, J. and Bates, D. 2013. Mixed-effects models in S and S-Plus. Springer, New York, $528 \mathrm{p}$.

Tate, M. C. and Clarke, D. B. 1995. Petrogenesis and regional tectonic significance of Late Devonian mafic intrusions in the Meguma Zone, Nova Scotia. Canadian Journal of Earth Sciences, 32, pp. 1883-1898. https://doi. 
org/10.1139/e95-145

Whitney, D. L. and Evans, B. W. 2010. Abbreviations for names of rock-forming minerals. American Mineralogist, 95, pp. 185-187. https://doi.org/10.2138/am.2010.3371

Wiedenbeck, M., Allé, P., Corfu, F., Griffin, W. L., Meier M., Oberli, F., von Quadt, A., Roddick, J. C., and Spiegel, W. 1995. Three natural zircon standards for U-Th-Pb, Lu-Hf, trace element and REE analyses. Geostandards Newsletter-the Journal of Geostandards and Geoanalysis, 19, pp. 1-23. https://doi.org/10.1111/j.1751-908X.1995. tb00147.x

Wright, W. J. 1934. Preliminary report of the granite industry of St. George, Charlotte County, N. B. New Brunswick Department of Lands and Mines, Mining Section, Paper, 34-1, $31 \mathrm{p}$.

\section{APPENDIX: FIELD AND LABORATORY METHODS}

\section{Field}

Without the random frost damage to the Baxter headstone, this project would not have taken place. With the permission of the Ritcey family of Riverport, Nova Scotia, we were able to acquire an essential second sample of Titanic material. The zircon age of ca. $420 \mathrm{Ma}$ guided the search regionally, whereas the distinctive texture of the Titanic headstones, by comparing a polished slab of Ritcey with early $20^{\text {th }} \mathrm{C}$. headstones in cemeteries, guided the search locally. When strong textural matches occurred with headstones in southwestern New Brunswick, the search for quarries began. When a mineralogical-textural match occurred in the Hanson quarry, detailed geochronology, mineral compositions, and whole-rock compositions began.

\section{Geochronology (University of New Brunswick)}

The target zircon grains were dated in situ in polished thin sections using an Australian Scientific Instruments (formerly Resonetics) RESOlution ${ }^{\mathrm{TM}}$ Series M-50-LR 193nm excimer laser ablation system and Laurin Technic Pty S-155 two-volume ablation cell which was coupled, via $4 \mathrm{~mm}$ OD Nylon $^{\mathrm{Tm}}$ tubing, with an Agilent 7700x quadrupole ICPMS equipped with dual external rotary pumps. Samples and standards were loaded together and the cell repeatedly evacuated and backfilled with He to remove all traces of ambient atmosphere from the cell. Image overlays were used to locate the target grains. Ablation was conducted using a 45 $\mu \mathrm{m}$ diameter laser crater pulsed at $3 \mathrm{~Hz}$ using a fluence of $\sim 4$ $\mathrm{J} / \mathrm{cm}^{2}$. Each ablation lasted $30 \mathrm{sec}$ and was preceded by $30 \mathrm{sec}$ of gas background collection. Ablation sequences included up to five analyses of NIST610 reference glasses throughout the sequence, and at least 15 well-characterized $\mathrm{U}-\mathrm{Pb}$ age standards that were distributed so as to bracket blocks of 3 to 5 unknowns. Ablated aerosols were carried out of the cell using a combination of $\mathrm{He}(300 \mathrm{~mL} / \mathrm{min})$ and $\mathrm{Ar}(930 \mathrm{~mL} /$ min). This was mixed with $2.0 \mathrm{~mL} / \mathrm{min} \mathrm{N}_{2}$, which is used to enhance ionization efficiency in the ICP-MS plasma. Before entering the ICP-MS torch, the combined gas stream passes through a smoothing device (Laurin Technic "squid"). The Agilent 7700x ICP-MS was operated at an RF power of $1500 \mathrm{~W}$ with ion lenses tuned to obtain $<0.3 \% \mathrm{ThO}^{+}$/ $\mathrm{Th}^{+}$and $\mathrm{U}^{+} / \mathrm{Th}^{+} \sim 1.05$ as measured on NIST610 reference glasses. One sweep of the ICP-MS quadrupole comprised the following masses and dwell times (in milliseconds): ${ }^{90} \mathrm{Zr}$ (10), ${ }^{202} \mathrm{Hg}(40),{ }^{204} \mathrm{~Pb}(60),{ }^{206} \mathrm{~Pb}(30),{ }^{207} \mathrm{~Pb}(70),{ }^{208} \mathrm{~Pb}(10)$, ${ }^{232} \mathrm{Th}(10)$, and ${ }^{238} \mathrm{U}(20)$. This gave a total measurement time of $\sim 0.25$ seconds per sweep or $\sim 120$ measurements per 30 second ablation. Mass ${ }^{202} \mathrm{Hg}$ was monitored to allow peak-stripping of ${ }^{204} \mathrm{Hg}$ from ${ }^{204} \mathrm{~Pb}$, using the measured ${ }^{202} \mathrm{Hg} /{ }^{204} \mathrm{Hg}$ for the background carrier gas, thereby ensuring the most accurate ${ }^{204} \mathrm{~Pb}$ correction, if necessary.

Zircon standard FC-1 (Pace and Miller 1993) was used for external calibration of U-Pb. Accuracy of the analytical conditions and data reduction scheme was verified using replicate analyses (typically 6 per session) of three additional zircon standards: Temora-2 (416 Ma; Black et al. 2003), 91500 (1065 Ma; Wiedenbeck et al. 1995) and an in-house zircon standard (708 Ma). We measured Concordia ages of $414 \pm 3 \mathrm{Ma}, 1065 \pm 4$ and $708 \pm 5$ respectively, confirming the accuracy of the method and data reduction. Concentration for $U$ and Th were calculated with reference to NIST610 glass using an estimate of $44 \mathrm{wt} \% \mathrm{Zr}$ for internal standardization.

The ICP-MS data file (data as counts/sec) and laser sequence log file were combined offline in Iolite v. 2.5 (Paton et al. 2011) and ages calculated using the VizualAge U-Pb geochronology data reduction scheme described by Petrus and Kamber (2012). An exponential down-hole $\mathrm{Pb} / \mathrm{U}$ fractionation correction and "automatic" spline fitting were used. The overall philosophy in establishing integration intervals during data reduction was foremost to exclude portions of the time-series that did not encounter zircon (e.g., either by drilling through a grain or missing the target) based on the net ${ }^{90} \mathrm{Zr}$ signal. Next, integrations were selected to encompass domains with constant ${ }^{207} \mathrm{~Pb} /{ }^{206} \mathrm{~Pb}$ value indicative of a single age domain. Whenever appropriate, the integration interval was additionally adjusted so as to achieve concordancy (within error) between ${ }^{206} \mathrm{~Pb} /{ }^{238} \mathrm{U},{ }^{207} \mathrm{~Pb} /{ }^{235} \mathrm{U}$, and ${ }^{207} \mathrm{~Pb} /{ }^{206} \mathrm{~Pb}$ ages. This could sometimes be achieved with minimal adjustment of the integration interval. Final errors are reported by Iolite and VizualAge as 20_prop_2SE and these represent errors intermediate between $1 \sigma$ and $2 \sigma$ standard deviations owing to the fact that Iolite incorporates an "excess" error term propagated from the scatter in the population of calibration standards (Paton et al. 2010). The population of 15 or so calibration standards is typically refined on a spot-by-spot basis to achieve MSWD $<1.5$, thereby minimizing excess error. The LA-ICP-MS used in 
this study incorporates high-capacity (Vici Metronics) Hg traps that help reduce background ${ }^{204} \mathrm{Hg}$ to $<125 \mathrm{cps}$. In cases where net ${ }^{204} \mathrm{~Pb}$ counts were encountered within an ablation time series and internal $2 \sigma$ errors on net ${ }^{204} \mathrm{~Pb} \mathrm{Cps}$ were $<20 \%$, a ${ }^{204} \mathrm{~Pb}$-based common $\mathrm{Pb}$ correction was applied using common $\mathrm{Pb}$ composition estimates based on the equations given in Kramers and Tolstikhin (1997). In cases where net ${ }^{204} \mathrm{~Pb}$ Cps were low ( $<100 \mathrm{Cps}$ ) but the Andersen (2002) calculation suggested a small residual common $\mathrm{Pb}$ component, the ${ }^{208} \mathrm{~Pb}$-based common $\mathrm{Pb}$ correction was applied. Otherwise, data for which the measured ${ }^{206} \mathrm{~Pb} /{ }^{204} \mathrm{~Pb}$ was large $(>10000)$ and the calculated $\% \mathrm{~Pb}^{\star}$ was $>99.7 \%$, the data are listed as uncorrected for common $\mathrm{Pb}$.

\section{Chemical compositions}

Although we strove for the greatest possible analytical accuracy in every analytical procedure we used in this investigation, therelativeconcentrations ofmineralsand rocks in the Titanic headstones and other materials, run at the same time, were more important than absolute concentrations.

\section{Electron microprobe olivine analysis}

(Dalhousie University).

We determined the olivine compositions using a JEOL 8200 Superprobe in WDS mode at the Department of Earth Sciences at Dalhousie University. Experimental conditions were $15 \mathrm{kV}$ and $20 \mathrm{nA}$, with spot sizes of $1 \mu \mathrm{m}$, and counting times of $40 \mathrm{~s}$, using internationally accepted natural minerals as standards and olivine 174.1 as a control.

\section{LA ICP-MS augite trace-element analysis (University of New Brunswick)}

Our spot size was set to $60 \mu \mathrm{m}$ with a laser energy of $4 \mathrm{~J} /$ $\mathrm{cm}^{2}$ and a repetition rate of $3 \mathrm{~Hz}$. We ran $40 \mathrm{~s}$ ablations with a $30 \mathrm{~s}$ gas background before each spot. Our two standards used were NIST610 as our primary concentration standard, and $\mathrm{BCR}-2 \mathrm{G}$ as our QC standard. We had very good running conditions and monitored oxide production $\left(\mathrm{ThO}^{+} / \mathrm{Th}^{+}<\right.$ $0.1 \%)$ and doubly charged ion production $\left({ }^{44} \mathrm{Ca}^{++} /{ }^{44} \mathrm{Ca}^{+}<\right.$ $0.15 \%$ ), so resulting interferences were kept at a minimum. Dwell times for most isotopes were set to $20 \mathrm{~ms}$, except for some major elements $(\mathrm{Mg}, \mathrm{Si}, \mathrm{Ca})$ which were set to $10 \mathrm{~ms}$.

The rims of a total of nine augite grains from THH, HQB, HDG, and ABG were analyzed for seven major elements and 35 trace elements on three separate occasions. From the trace-element group, we excluded $\mathrm{Nb}, \mathrm{Sn}, \mathrm{Ba}, \mathrm{Ta}, \mathrm{Pb}, \mathrm{Th}$, and $\mathrm{U}$ for crystal chemical reasons (ionic radius and charge), as well as for their low concentrations (ranging from $<1 \mathrm{ppm}$ to $<<1 \mathrm{ppm}$ ) and large variances. Also, because of small differences among the three sets of analyses, all individual spot analyses were normalized to the mean of the THH augite composition for that run. We then made box plots for each of the seven major elements and 28 trace elements to determine outliers (defined as any point lying outside the "fences" representing 1.5 times the interquartile distance from the median). For some elements, removal of outliers from the original data leads to the creation of new outliers, but these were not excluded from the subsequent statistical analysis. Table A1 summarizes the rejection of the outliers (4.1\% of major-element determinations and $4.2 \%$ of traceelement determinations). In the case of the trace elements, $95 \%$ of the outliers were greater than the "fence", and almost certainly represent micro-inclusions of other phases in the augite. The outlier-removed matrix of THH-normalized ratios constitutes the data set used for statistical analysis.

\section{Whole-rock major and trace-element analysis (Bureau Veritas)}

We sent a combination of hand samples and pulverized rock material to a commercial analytical laboratory, Bureau Veritas Commodities, in Vancouver, BC. Their LF200 analytical package uses ICP-MS for all determinations. The major elements typically report results within $5-7 \%$ precision. Other elements have precisions of $10-15 \%$ of the amount present.

Table A1. Summary of augite outliers.

\begin{tabular}{lcc}
\hline & Majors & Traces \\
\hline Total Grains (THH-HQB-HDG-ABG) & $3-2-3-1=9$ & $3-2-3-1=9$ \\
Total Craters (THH-HQB-HDG-ABG) & $24-19-23-17=83$ & $46-39-23-17=85$ \\
Total Determinations (Craters x Elements) & 581 & 2380 \\
Total Outliers & 24 & 100 \\
Percent Outliers & 4.1 & 4.2 \\
High (Above Upper Fence) & 16 & 95 \\
Low (Below Lower Fence) & 8 & 5 \\
\hline
\end{tabular}

Notes: Abbreviations THH - Titanic Headstones; HQB - Hanson Quarry; HDG -

Home Depot ${ }^{\text {tix }} ;$ ABG - Atwoods Brook.

Editorial responsibility: Sandra M. Barr 